\title{
Een Netwerkanalyse naar 'Resilience': Binnen een Individueel en Multilevel Netwerk
}

Daan Blankenstijn

Universiteit: Universiteit van Amsterdam (UvA)

Bachelorthese Psychologie

Studentnummer: 10555889

Woorden: 6,274

Datum: 29-06-2018

Supervisor: Gaby Lunansky 


\section{Abstract}

De mate van samenhang tussen resilience en affect states werd bekeken door middel van individuele en multilevel netwerken. Aan het onderzoek hebben 31 deelnemers meegedaan. Voor de meting van affect states is een aangepaste SCL-90 symptoom checklist gebruikt en als operationalisatie van resilience is een vraag over controle toegevoegd. Deelnemers werd gevraagd gedurende twee weken driemaal daags de checklist in te vullen. Hoewel de netwerken veel verschilden, bleek er een aantal positieve verbindingen te zijn tussen Controle en positieve affect states en negatieve verbindingen tussen Controle en negatieve affect states. Door middel van netwerken is de aard van resilience onderzocht op de persoonsgeörienteerde, en over tijd fluctuerende manier die het construct verlangt.

Het blijkt dat mensen gedurende hun leven minimaal met één levensbedreigende of gewelddadige situatie te maken krijgen (Ozer, Best, Lipsey \& Weiss, 2003; aangehaald in Bonanno, 2004). Sommigen ervaren onder deze omstandigheden erg veel stress en herstellen niet of traag, terwijl anderen weinig lijden en er sneller bovenop zijn. Personen in deze laatste categorie worden resilient genoemd. Hoewel er lang werd gedacht dat resilience (1) weinig voorkwam, (2) een aanwijzing voor ontkenning of vermijding was of (3) dat deze mensen later rouw zouden voelen (Bonnano, 2004), blijkt uit onderzoek geen empirisch bewijs voor deze bevindingen. Uit het artikel van Bowlby (1980) kwam zelfs naar voren dat de afwezigheid van rouw een aanwijzing kan zijn voor pathologie, aangezien deze mensen als koud en afstandelijk gezien worden (aangehaald in Bonanno, 2004). Bonanno en Wortman (2002) lieten echter in een onderzoek zien dat na de dood van een echtgenoot 46\% van de deelnemers een laag niveau van depressie liet zien, tijdens een interview geen afstandelijke indruk maakte en aangaf geen moeilijkheden te hebben in andere relaties. Tegelijkertijd lieten deze personen een hoge score zien op aanpassingsvermogen bij verlies en werd er geen duidelijke uitgestelde rouw gevonden bij deze personen. De drie vooraf gestelde bevindingen blijken volgens dit onderzoek niet zo stellig benoemd te kunnen worden en geven aanwijzing voor het bestaan van resilience. Daarbij blijkt de aanname dat resilience niet vaak voorkomt door dit onderzoek ook in kracht af te nemen. De toegenomen interesse in het fenomeen resilience is goed te begrijpen, ook binnen de psychopathologie. Uit een longitudinaal onderzoek van Collishaw et al. (2007) werd 
duidelijk dat kinderen die vroeger het slachtoffer zijn geweest van mishandeling een aanzienlijk risico lopen op psychopathologie in hun latere leven. Uit dit onderzoek bleek echter een substantieel deel van de mishandelde kinderen geen psychiatrische klachten te vertonen. Deze individuen vertoonden hoge scores op verschillende resiliencefactoren en kunnen ook als resilient worden bestempeld.

Bovenstaande bevindingen laten zien dat er veel mensen in staat zijn resilience te vertonen, en zetten grote vraagtekens bij verschillende niet empirisch onderbouwde aannames. Bovendien geven resilience-factoren aanwijzingen voor het voorkomen van het ontwikkelen van psychopathologie op latere leeftijd. Om deze redenen is het interessant om te kijken naar de oorzaken van resilience, met welke andere aspecten resilience gepaard gaat en hoe resilience eventueel verhoogd kan worden.

Resilience is een term die in veel literatuur gebruikt wordt, maar op verschillende manieren wordt gedefinieerd. De definitie die Luthar, Cicchetti en Becker (2000) in hun artikel gebruiken is "een dynamisch proces dat gepaard gaat met positieve aanpassing in de context van significante tegenslagen". Masten en haar collega's hebben vervolgens drie omschrijvingen gemaakt die beschouwd kunnen worden als resilience: 1) risicovolle individuen laten uitkomsten zien die boven verwachting zijn, 2) positieve aanpassing blijft ondanks stressvolle ervaringen, en 3) er is een goed herstel van traumatische ervaringen (Masten 1994; Masten et al., 1990; aangehaald in Luthar et al., 2000). Uit onderzoek bij kinderen kwam naar voren dat resilience is opgebouwd uit verschillende factoren: 1) de attributen van een kind zelf, 2) aspecten van de familie, en 3) karakteristieken van de bredere omgeving (Masten \& Garmezy, 1985; Werner \& Smith, 1982, 1992; aangehaald in Luthar et al., 2000). Er zijn veel voorbeelden te noemen die onder deze verschillende factoren van resilience vallen: 1) attributen van iemand zelf zoals bijvoorbeeld intelligentie, persoonlijkheid en fysieke aantrekkingskracht 2) aspecten van de familie zijn huishoudens met structuur en regels en ondersteuning van de ouders, en 3) voorbeelden van karakteristieken van de bredere omgeving zijn goede leraren en vrienden voor emotionele steun (Werner, 1995).

Zoals te lezen valt, bestaat resilience uit veel verschillende factoren en is het moeilijk, als niet onmogelijk, één sluitende definitie te geven. Uit de discussie van het 
artikel van Luthar et al. (2000) komt als advies naar voren dat resilience gemeten moet worden op een manier die gericht is op een persoonsgeörienteerde statistische methode (Bergman \& Magnusson, 1997; Cichetti \& Rogosch, 1996; Luthar \& Cushing, 1999; aangehaald in Luthar et al., 2000). De reden hiervoor is dat resilience per persoon een andere structuur kan hebben. Zo zijn er voor mensen met een risico voor antisociale persoonlijkheden door familie omstandigheden andere resilience factoren belangrijk dan voor mensen met een mood disorder (Luthar et al., 2000). Hierom is het belangrijk om resilience in een individueel netwerk te vangen.

Voor lange tijd is men er vanuit gegaan dat er in de psychopathologie een latente variabele bestaat (het sydroom), die de symptomen veroorzaakte. Om pragmatische methodologische redenen is deze manier lang aangehouden: het was de enige manier van meten (Cramer \& Borsboom, 2013). $\mathrm{Nu}$ is er een nieuwe manier van het conceptualiseren van psychologische constructen, namelijk door middel van netwerk modellen. Netwerk modellen gaan ervan uit dat aandoeningen geconceptualiseerd worden als causaal verbonden symptomen in plaats van effecten van een latente variabele (Cramer \& Borsboom, 2013). Deze aanname lijkt plausibel, aangezien aandoeningen een grote variabiliteit hebben in hun oorzaak (Kendler, 2005a, NolenHoeksma \& Watkins, 2011, Zachar \& Kendler, 2007; aangehaald in Cramer \& Borsboom, 2013) wat betekent dat er voor één specifieke aandoening, niet één specifieke latente variabele kan zijn. Verder bewijs voor de opbouw van aandoeningen komt uit recent onderzoek van Fried, Epskamp, Nesse, Tuerlinckx en Borsboom (2016) naar Major Depression (MD). Bij een onderzoek naar ruim 3,000 mensen met MD blijkt dat de symptomen voor deze aandoening significante verschillen laten zien per individu in hun mate van verbondenheid met andere symptomen. Daarbij bleek zelfs dat niet-DSM symptomen even veel verbondenheid laten zien als sommige DSM symptomen. Een netwerk model geeft een waarschijnlijkere weerspiegeling van de opbouw van de psychologische constructen.

Een netwerk bestaat uit verschillende 'nodes' die met elkaar door middel van verbindingen genaamd 'edges' in verband staan. Het is een dynamisch geheel, waarin de verschillende nodes elkaar wederzijds beïnvloeden en in verschillende mate in verband staan met elkaar. Verder is het voor dit stuk belangrijk om te weten dat nodes elkaar 
door middel van feedback loops op verschillende meetmomenten kunnen versterken/verzwakken in een temporeel netwerk (Cramer \& Borsboom, 2013). In de methode sectie zal de uitleg over het gebruik van een temporeel netwerkmodel nog uitgebreider worden besproken. Een netwerk model heeft als groot voordeel dat het de onrealistische assumptie van één causale veroorzaker niet heeft. Uit veel studies is naar voren gekomen dat er 'multiple pathways to resilience' zijn (Luthar, Doernberger \& Zigler, 1993; Rutter, 1987; aangehaald in Bonanno, 2004). Daarbij blijkt het, zoals eerder benoemd, dat resilience een multidimensioneel karakter heeft. Dat wil zeggen dat resilience samenhangt met veel verschillende factoren, die onder meer variëren op verschillende tijden (Connor \& Davidson, 2003). Ook werd uit de discussie van het artikel van Luthar et al. (2000), zoals eerder genoemd, duidelijk dat resilience op een persoonsgeoriënteerde manier gemeten moet worden en dat er meer aandacht moet komen voor de "bidirectionele natuur van verbindingen tussen de beschermende factoren van resilience". Ten slotte heeft resilience een dynamisch karakter (definitie van Luthar et al., 2000) en is het belangrijk om dit begrip op een dynamische manier te analyseren.

Door het gebruik van een netwerk model kunnen de volgende punten duidelijk in kaart worden gebracht omdat (1) de verschillende 'pathways to resilience' in een netwerk geanalyseerd worden door middel van de sterkte van de partiële correlatie tussen de knopen. (2) Het multidimensionele karakter van resilience wordt in kaart gebracht door een resilience-factor toe te voegen in een persoonlijk netwerk en te bekijken met welke knopen deze factor sterk en zwak samenhangt,. (3) Door middel van feedbackloops kan in het netwerk ook de bidirectionele natuur van resilience worden bekeken. Ten slotte (4) is een temporeel netwerk in staat het dynamische karakter van resilience te analyseren door te bekijken hoe de resilience-factor zich manifesteert over verschillende meetmomenten.

Zoals uit eerder onderzoek blijkt, worden er veel verschillende factoren gevonden die een sterke samenhang met resilience vertonen en is de vinger niet te leggen op één zere plek. Uit het artikel van Connor en Davidson (2003) bijvoorbeeld blijkt dat er in de afgelopen twintig jaar onderzoek is gedaan naar resilience en blijkt dat deze term varieert in context, tijd, leeftijd, sekse en culturele achtergrond. Connor en 
Davidson hebben in hun artikel een korte vragenlijst gemaakt met als doel het kwantificeren van resilience: de CD-RISC (2003). Momenteel wordt deze vragenlijst erkend als de meest gebruikte en gevalideerde schaal voor het meten van resilience met items over persoonlijkheidskarakteristieken, geloof en attituden (Windle, Benett \& Noyes, 2011; aangehaald in Wolf et al., 2018). Uit een Factor Analyse bleek dat de factor met de hoogste 'eigenvalue' (7.47) een factor was die gepaard gaat met gevoel van competentie, hoge standaarden en vasthoudendheid; oftewel 'hardiness'. Zo komt uit het artikel van Bonanno (2004) voort dat een hoge mate van hardiness een buffer kan vormen ten aanzien van blootstelling aan grote vormen van stress (Kobasa, Maddi \& Kahn, 1982; aangehaald in Bonanno, 2004) en dat 'hardy' individuen mogelijk stressvolle situaties beoordelen als minder stressvol en daardoor stressverlagend kunnen werken (Bonanno, 2004). Daarbij blijkt volgens het 'Protective Factor Model of Resilience', waar een beschermende factor interacteert met een stressor om de waarschijnlijkheid op een negatieve uitkomst te verlagen, dat hardiness een grote resilience factor is (Steinhardt \& Dolbier, 2008). Ook uit het artikel van Maddi et al. (2012) blijkt dat mensen die een hardiness houding hebben meer gemotiveerd zijn om stress te overwinnen. Hardiness blijkt uit deze onderzoeken een negatieve relatie met stress te hebben en sterk samen te hangen met resilience.

Hardiness is opgebouwd uit drie componenten: toewijding, controle en uitdaging (Kobasa, 1979; Maddi \& Kobasa, 1984; aangehaald in Maddi et al., 2012). Omdat het interessant is om te kijken naar het dynamische aspect van resilience, zullen we in het huidige onderzoek knopen kiezen die dagelijks fluctueren. Aangezien toewijding en 'problemen zien als uitdagingen' meer statische persoonlijkheidskenmerk zijn (en hoogstwaarschijnlijk niet veel fluctueren), is het doel om in dit onderzoek de component 'gevoel van controle' toe te voegen aan het netwerk. Door middel van ESM data (zie methode sectie) zullen we deze knoop proberen te vangen in de verschillende netwerken.

Controle kan volgens de 'Cognitive Appraisal Theory' beschreven worden door middel van de 'cognitive appraisal processes'. Hierbij wordt de primary appraisal gezien als de evaluatie van een persoon op een evenement wat betreft het welzijn (dus goedaardig of stressvol). De secondary appraisal gaat meer over 'wat kan ik doen?'. 
Hierbij worden mogelijke coping-mechanismen overwogen. Het effect van 'gevoel van controle' zit in het volgende: volgens de theorie zijn de verwachtingen van controle gekoppeld aan de primary appraisal. De primary appraisal heeft als gevolg dat een stressvolle situatie als bedreiging of uitdaging gezien kan worden. Vervolgens wordt de secondary appraisal ('wat kan ik doen?') geactiveerd. Als men een hoge mate van algemeen geloof van controle heeft, ziet men als primary appraisal een situatie als een uitdaging en is men eerder geneigd om als secondary appraisal een 'problem focussed' manier van coping te gebruiken, waarbij wordt gekeken naar oplossingen van een probleem (Lazarus \& Folkman, 1984; aangehaald in Baker \& Berenbaum, 2007). Volgens deze theorie wordt er verwacht dat dit geloof van controle, ook wel internal locus of control, de negatieve effecten van stress vermindert (ook gevonden in Johnson \& Sarason, 1978; Kobasa, 1979; aangehaald in Sandler \& Lakey, 1982) en een positieve relatie heeft met positieve affect states (ook gevonden in Warehime \& Woodson, 1971; Pannells \& Claxton; 2008). Aangezien stress een uniek hoge positieve associatie heeft met zorgen maken (Szabó, 2011), wordt er specifiek verwacht dat Controle negatief in verband staat met Zorgen Maken.

Folkman (1984) laat zien dat volgens de 'Cognitive Theory of Stress and Coping', stress in veel situaties en tijdsmomenten kan fluctueren. De cognitieve theorie is gebaseerd op een relationeel- en een proces georiënteerd deel, waarin het relationele deel stress ziet als een relatie tussen de persoon en de omgeving en het proces deel de relatie tussen de persoon en de omgeving als dynamisch ziet, die wederzijds invloed op elkaar hebben (Folkman, 1984). Volgens Folkman (1984) betekent dit dat controle volgens het relationele perspectief alleen gezien kan worden vanuit een specifieke persoon-omgeving relatie en dat volgens het proces perspectief het gevoel van controle kan variëren als gevolg van de persoon-omgevings relatie (Folkman, 1984).

Gezien de definitie van resilience van Luthar et al. (2000) over positieve aanpassingen op tegenslagen, is het van belang om te kijken of deze aanpassingen te zien zijn in affect states in verhouding tot resilience. Een affect state wordt gebruikt om iemands staat van emotie of gevoel te beschrijven (wikipedia, z.j.). Affect states kunnen positief of negatief zijn (valentie), en kunnen veel of weinig arousal vertonen, ook wel actief of passief. Aangezien hardiness bestaat uit drie componenten, waarvan er twee 
waarschijnlijk weinig variantie vertonen, is het doel om in dit onderzoek te kijken naar de component Controle, aangezien deze volgens het relationele- en proces perspectief wel varieert.

Aangezien de deelnemers binnen deze studie niet gecategoriseerd worden als risicovol en geen trauma hebben, zal resilience gemeten worden volgens de tweede categorie van Masten (1994): 'positieve aanpassing blijft ondanks het voorkomen van stressvolle ervaringen'. Dit onderzoek bekijkt de mechanisme(n) van resilience binnen een persoon door het gebruik van een netwerk-model. Op deze manier kan in kaart worden gebracht welke relaties affect states met elkaar hebben. Uit het artikel van Luthar et al. (2000) wordt gesteld dat de kennis over resilience zeer beperkt blijft als er niet gewerkt wordt vanuit een theoretisch kader (Luthar et al., 2000): er moet meer gestreefd worden naar hoe de mechanismen werken (Cowen et al., 1997; Luthar, 1999, aangehaald in Luthar et al., 2000). Veel onderzoek over resilience is tot op heden vooral empirisch gedreven. In huidig onderzoek wordt volgens de Cognitive Appraisal Theory verwacht dat de factor Controle een factor is van resilience. Verwacht wordt dat in het persoonlijke netwerk model deze knoop een positieve relatie heeft met positieve 'affect states' als Enthousiasme, Energie en Tevredenheid, aangezien hardiness stressverlagend werkt en als buffer tegen stressvolle situaties kan werken (Bonanno, 2004) . Als gevolg van de negatieve relatie met stress, wordt er verder verwacht dat resilience een negatieve relatie heeft met 'affect states' als Onzekerheid, Niet Goed Voelen en voornamelijk Zorgen Maken.

\section{Methode}

Deelnemers

Deelnemers voor het onderzoek zijn gevonden door middel van gebruik van eigen netwerk en door middel van het LAB van de Universiteit van Amsterdam. In totaal hebben er 31 deelnemers, waarvan 26 deelnemers hebben gekozen hun demografische gegevens te delen. De verdeling van de deelnemers bestond uit 17 vrouwen en 9 mannen, met gemiddelde leeftijd 29,6 $(S D=15,6)$. Eerstejaars Psychologiestudenten $(\mathrm{N}=7)$ kregen voor het onderzoek 4,5 proefpersoonpunt toegekend, overige deelnemers $(\mathrm{N}=24)$ kregen voor hun deelname geen vergoeding. 


\section{Materialen}

In het huidige onderzoek is er gebruik gemaakt van een aangepaste symptoom SCL-90 checklist bestaande uit 11 stellingen over affect states met extra node 'controle'. De vragen uit de survey zijn gebaseerd op hun mate van variantie en variatie in positieve/negatieve en actieve/passieve affect states. Voorbeelden uit de vragenlijst zijn "I am cheerful" en "I feel unsure". De gehele survey is bijgevoegd in Appendix B. Controle zal gemeten worden door de vraag "I feel in control", die gebaseerd is op de theorie over het gevoel van controle. De stellingen werden beantwoord op een 7-puntsschaal lopend van score 1 tot 7 .

\section{Procedure}

Voor dit onderzoek is ESM-data verzameld. Bij ESM worden deelnemers in korte tijd herhaaldelijk gemeten (Epskamp et al., 2017). In dit onderzoek werd er gedurende twee weken driemaal daags (met windows of measurement van 08:00-11:00, 13:0016:00 en van 18:00-21:00) de aangepaste symptoom SCL-90 checklist ingevuld. De datacollectie is gedaan met de applicatie 'Real Life Exp', een applicatie van 'Life Data'. Deelnemers aan het onderzoek werden allereerst gevraagd een consent form in te vullen waarin akkoord werd gegaan met het gebruik van de verzamelde data van de desbetreffende deelnemer. Dit consent form is bijgevoegd in Appendix C. Deelnemers werd vervolgens gevraagd de applicatie te downloaden en na 42 metingen ( 3 maal daags $\mathrm{x} 14$ dagen) te stoppen met het invullen van de survey.

\section{Analyses}

\section{Temporeel Netwerk}

In het huidige onderzoek zal gebruik worden gemaakt van een temporeel netwerk, waarin nodes elkaar wederzijds beïnvloeden over tijd (Epskamp et al., 2017). In dit model wordt een variabele in een 'window of measurement' (het meetmoment waarop iemand zijn gegevens rapporteert) voorspeld door dezelfde (autoregressive effect of feedback loop) of een andere variabele (cross-lagged effect) (Selig \& Little, 2012; aangehaald in Epskamp et al., 2017) in het voorgaande window of measurement. Deze autoregressive en cross-lagged effecten kunnen geschat en gevisualiseerd worden in een temporeel netwerk (Bringmann et al., 2013; aangehaald in Epskamp et al., 2017). De relatie tussen de twee edges kan gezien worden als een indicatie van causaliteit: er 
wordt een temporele verbinding verwacht als er een causaal verband is (Epskamp et al., 2017), echter betekent dit dus niet dat elke temporele verbinding gezien kan worden als een causaal verband. In een temporeel netwerk wordt een veroorzaker van een voorgaande window of measurement op het huidige, aangegeven door middel van een pijl van de ene node naar de andere (cross-lagged) of naar zichzelf (autoregressive) (Epskamp et al., 2017).

\section{Contemporaneous Netwerk}

Ook zal er gekeken worden naar de relaties van de nodes binnen één meetmoment die niet verklaard kunnen worden door de temporele effecten. Deze partiële correlaties zijn correlaties die zijn gecorrigeerd voor de temporele effecten en alle andere factoren in hetzelfde meetmoment. In andere woorden worden de residuele correlaties die niet verklaard worden door de temporele effecten verklaard in een netwerk binnen eenzelfde meetmoment. Dit netwerk wordt het contemporaneous network genoemd (Epskamp, Waldorp, Mottus \& Borsboom, 2017; Fischer, Reeves, Lawyer, Medaglia \& Rubel, 2017; aangehaald in Epskamp et al., 2017). Verwacht wordt dat er meer relaties in het contemporaneous netwerk zullen zijn dan in het temporele netwerk, omdat een veroorzakend effect van de ene factor op de andere vaak plaatsvindt in een kwestie van seconden, terwijl bij de dataverzameling er een aantal uur zit tussen de meetmomenten (Epskamp et al., 2017). Hierdoor is dit effect lastig te vangen.

Belangrijk bij het interpreteren van beide soorten netwerken is om vooraf vast te stellen dat een netwerk alleen in staat is om hypothesen te genereren over de verbindingen tussen knopen en niet om een confirmatieve analyse uit te voeren (Epskamp et al., 2017). Dit komt door het feit dat er alleen geobserveerd wordt en geen data worden gemanipuleerd: er is dus geen experimentele opzet. Het is echter wel mogelijk om door middel van de centraliteit te kijken welke knopen het belangrijkst zijn en wellicht de moeite waard zijn om experimenteel te onderzoeken. Deze zogenaamde centrality measures (Constantini et al., 2015; Newman, 2010; Opstahl, Agneesens \& Skvoretz, 2010; aangehaald in Epskamp, 2017) kunnen helpen bij het analyseren van de knopen. Er zijn drie soorten centrality measures: Betweenness betekent de mate waarin een knoop op de kortste verbindingen tussen twee knopen ligt, Closeness meet hoe 
dichtbij een knoop bij alle andere knopen in het netwerk ligt en Strength meet de mate van associaties die een knoop met alle knopen in een netwerk heeft (Opsahl, Agneessens, \& Skvoretz, 2010).

\section{Resultaten \\ Individuele netwerkanalyse}

Zoals uit de inleiding van dit stuk naar voren kwam, is het belangrijk om resilience op een persoonsgeörienteerde manier te meten en wordt daarom in eerste instantie gekeken naar de individuele netwerken van de deelnemers. Als exclusiecriterium zijn allereerst de deelnemers die één of meer affect states niet hebben ingevuld of hebben overgeslagen in een sessie, niet meegenomen, waarna er nog 2.904 van de initiële 13.611 (21,33\%) datapunten overblijven. Vervolgens is er gekeken naar welke personen de twaalf stellingen gedurende 14 dagen driemaal daags hebben ingevuld (504 meetmomenten) of dit vaker hebben gedaan. Dit aantal meetmomenten is als ondergrens genomen voor het aantal meetmomenten voor het schatten van een individueel netwerk. Van de personen die meer dan 504 metingen hebben ingevuld, zijn de eerste 504 gebruikt voor het schatten van het individuele netwerk. Na toepassing van deze selectiecriteria zijn er nog vijf overgebleven deelnemers. De geschatte netwerken zijn te vinden in Appendix A. Aangezien de persoonlijke netwerken erg van elkaar verschillen, zal er in dit stuk één persoonlijk netwerk uitgebreid besproken worden ter illustratie, die in kleine mate vergeleken zal worden met een ander netwerk. De overige netwerken worden in Appendix A kort beschreven. De keuze van het individuele netwerk is gemaakt op basis van de hoeveelheid edges in zowel het contemporele- als temporele netwerk. Op deze manier kan het netwerk in theoretische zin beter worden besproken.

In Figuur 1 is het individuele netwerk van deelnemer 4 te zien. De individuele netwerken zijn geschat door het R-package 'graphicalVAR'. In het temporele netwerk (rechter figuur) zijn weinig (sterke) connecties te zien. Zoals werd beschreven was dit te verwachten, aangezien de tijd tussen de meetmomenten vrij lang is om zogenaamde indicaties van causaliteit te vinden. Theoretisch is er te zien dat Zorgen Maken een feedback loop heeft, wat inhoudt dat op meetmoment $\mathrm{T}$ je zorgen maken een grotere kans geeft op je zorgen maken op meetmoment T+1; Zorgen Maken versterkt zichzelf 
dus als het ware. Ook is een erg zwakke voorspellende positieve relatie van Enthousiasme op Irritatie te zien. In het contemporaneous netwerk (linker afbeelding) zijn 41 van de mogelijke 100 edges gevonden (41\%). In het netwerk komt naar voren dat Geïrriteerd en Boosheid relatief sterk positief met elkaar in verband staat en dat Zorgen Maken en Enthousiasme een sterke negatieve partiële correlatie vertonen. Verder is het opvallend dat bij deze persoon Geagiteerd en Vrolijk een sterk positief verband vertonen. Gerelateerd aan Controle, de operationalisatie van resilience, zijn ook een aantal opvallende dingen te zien. Controle vertoont een positieve correlatie met Energie en Tevredenheid, die op hun beurt weer een partiële correlatie met Enthousiasme en Ontspannenheid laten zien. Controle staat, zoals deels naar verwachting, in positief verband met een aantal positieve affect states. Er blijkt verder dat Controle een zwakke negatieve relatie vertoont met Zorgen Maken, wat specifiek verwacht werd uit het verband tussen resilience en stress. Verder heeft controle geen andere negatieve relaties die te vinden zijn met negatieve 'affect states', in tegenstelling tot de verwachting.
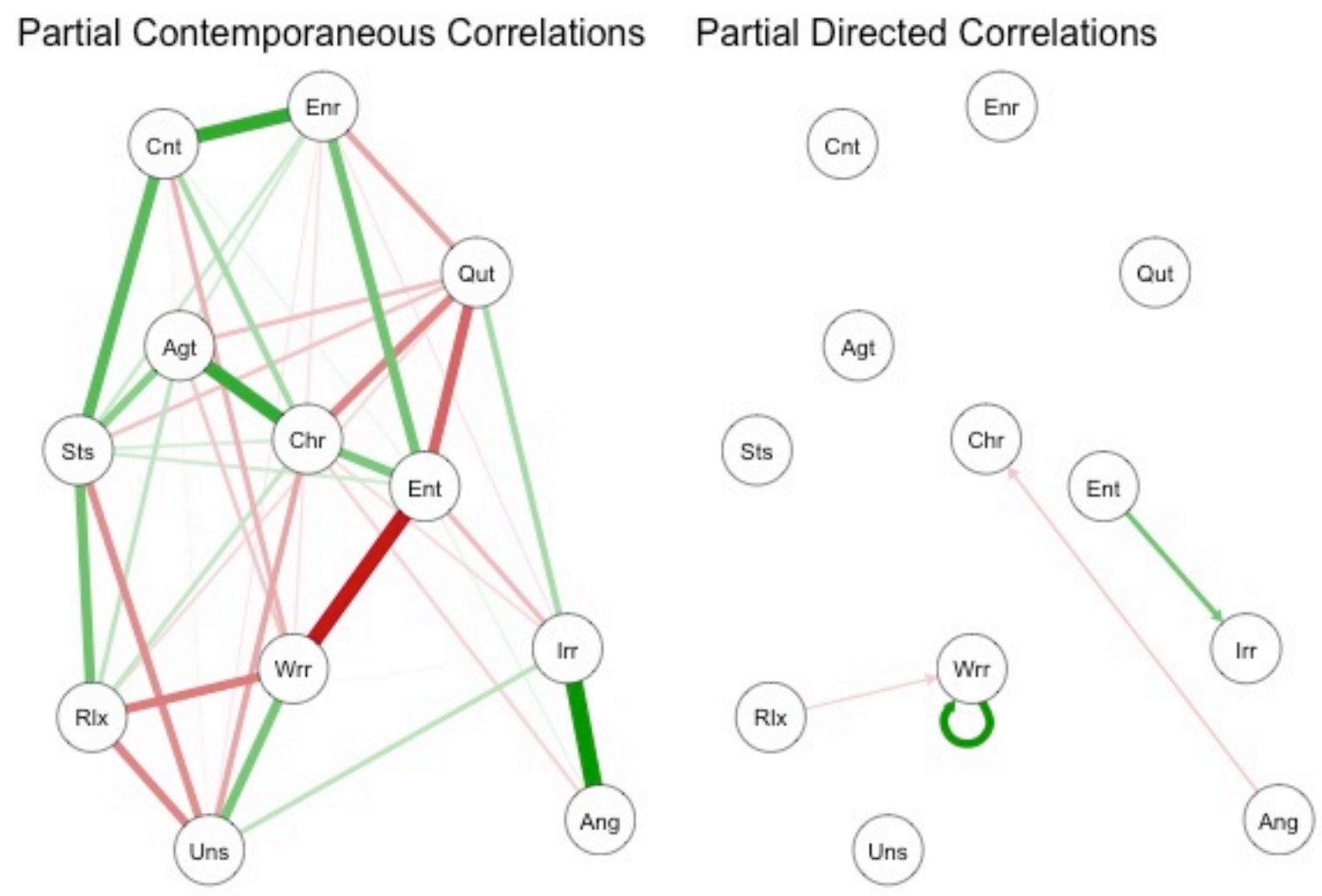

Figuur 1: Individuele netwerken persoon 4 
In het netwerk van persoon 4 is te zien dat de knoop Enthousiasme op elke schaal van de centrality measures het hoogst scoort en in dit netwerk als belangrijkste knoop gezien kan worden (Figuur 2). Opgewektheid laat ook een sterke mate van strength zien en heeft sterke associaties met alle andere nodes in het netwerk. Controle is in dit netwerk niet centraal en vertoont niet de mate van verbondenheid met andere factoren die van te voren verwacht werd.
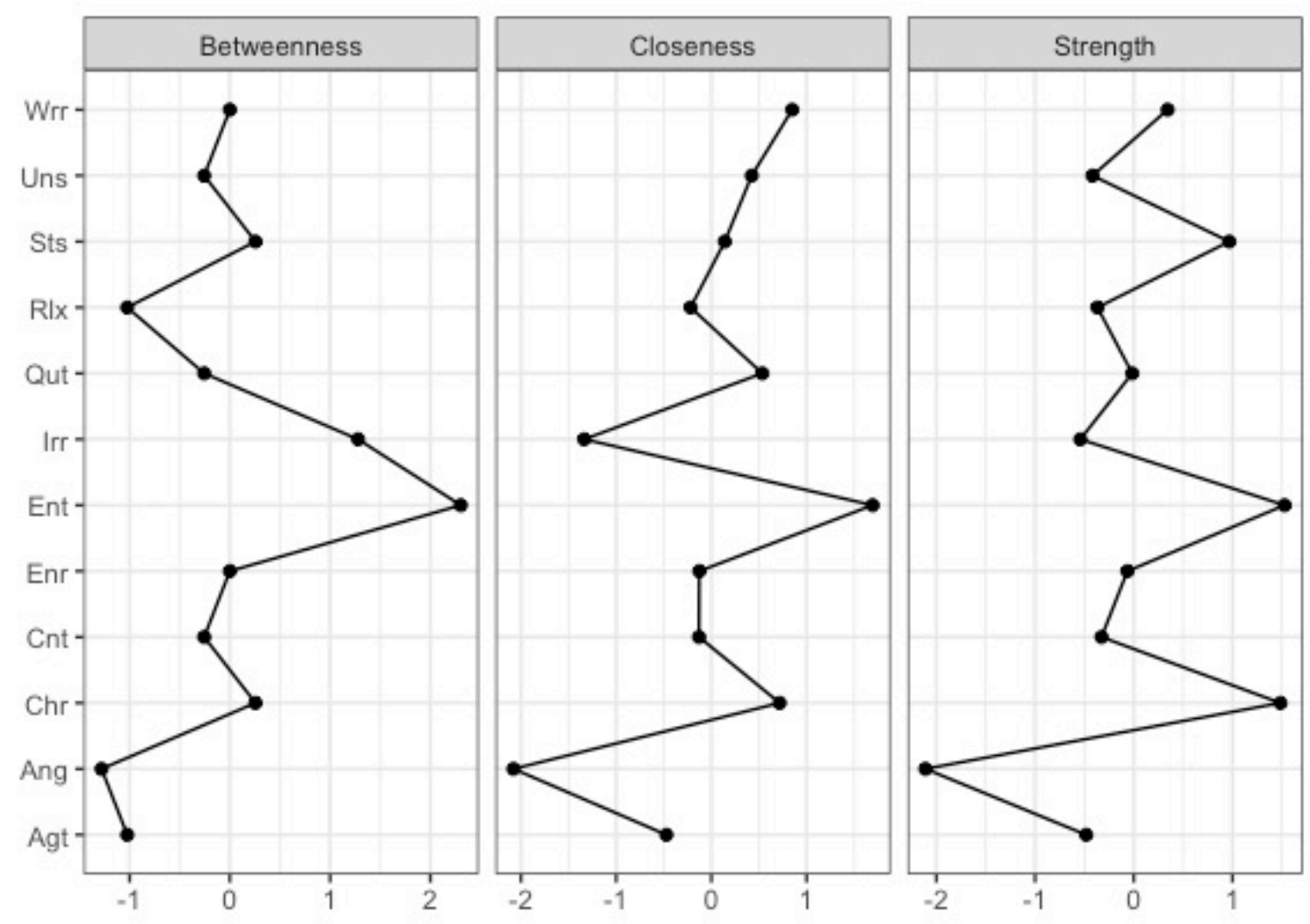

Figuur 2: Centraliteit persoon 4

Ter vergelijking is het individuele netwerk van persoon 5 in figuur 3 bijgevoegd. Hierin zijn minder edges gevonden dan bij persoon 6, 12 van 100 (12\%). In deze figuur zijn duidelijke verbindingen tussen de affect states Stil, Ontspannen en Tevreden, die allen gezien kunnen worden als een cluster van positieve passieve emoties. Ook is het interessant om te zien dat de factor Controle met zowel Opgewekt als Stil een positieve connectie heeft. Deze persoon kan door het gevoel van Controle een zowel een opgewekt als meer stil/rustig gevoel krijgen. Er ontbreken, tegen de verwachting in, negatieve relaties van controle met negatieve affect states. Verder zijn er geen verrassende 
connecties tussen de positieve en negatieve affect states. Ten slotte zijn er, in tegenstelling tot persoon 4 , geen temporele verbanden te vinden.
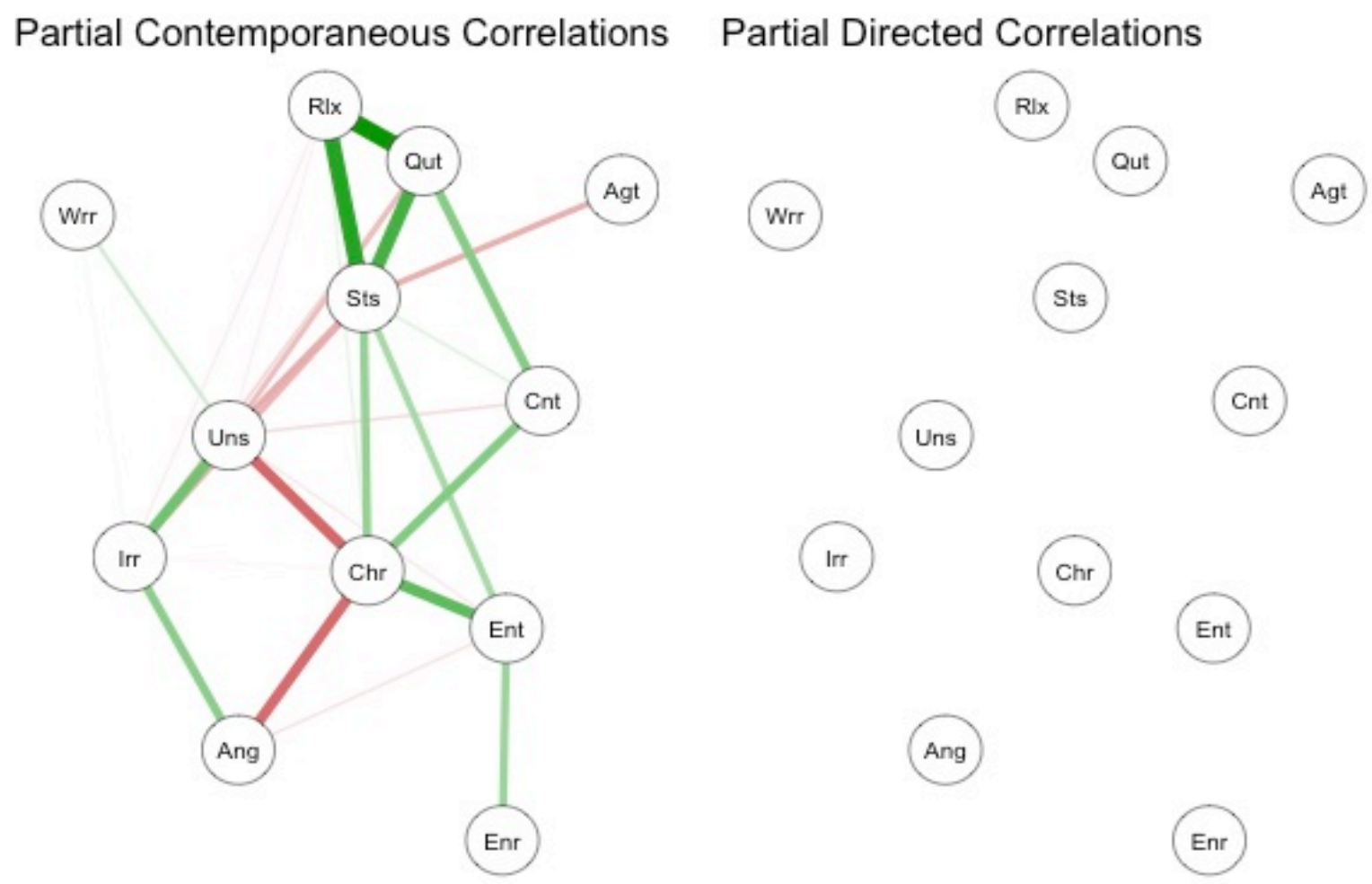

Figuur 3: Individuele netwerk persoon 5

Zoals te zien aan de centrality measures van persoon 5 zijn Tevredenheid en Opgewektheid de belangrijkste nodes in het netwerk en heeft ook hier Controle geen hoge centraliteit. 

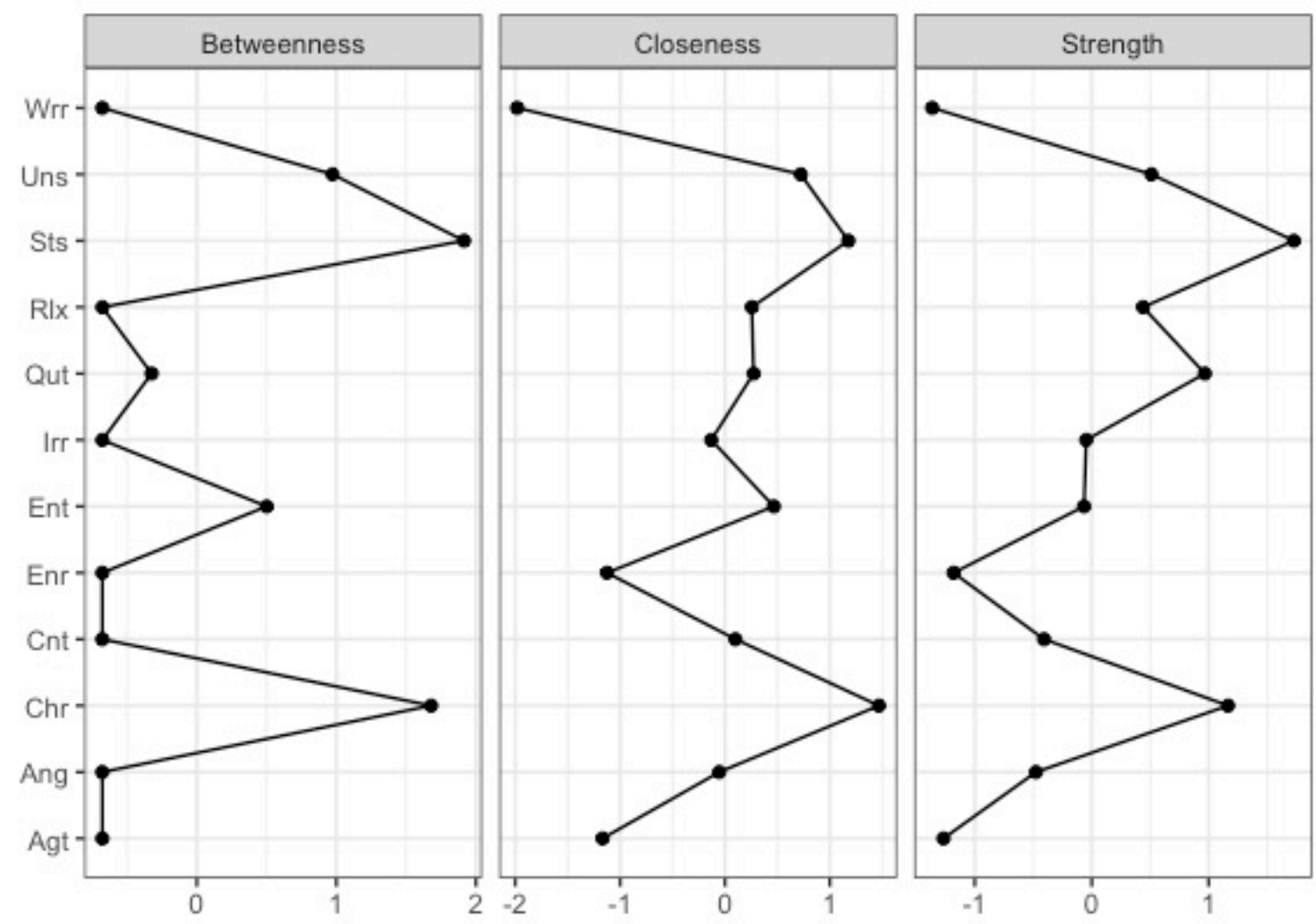

Figuur 4: Centraliteit persoon 5

Zoals blijkt uit deze, maar ook uit de andere individuele netwerken in Appendix A, verschillen de netwerken, zoals verwacht erg van elkaar. In alle individuele gevallen echter, blijkt de operationalisatie Controle in mindere mate in verband te staan met de affect states dan verwacht.

\section{Multilevel VAR}

$\mathrm{Nu}$ is het interessant om te kijken naar het gemiddelde netwerk van alle participanten met voldoende datapunten om te kijken hoe de mate van controle in dat netwerk ligt. Door middel van het R-package mIVAR kan er een netwerk model geschat worden voor een sample $\mathrm{N}>1$ met verschillende meetmomenten op een dag.

Voor de schatting van het multilevel VAR netwerk (nader te noemen mIVAR) zijn de sessies niet meegenomen waarvan één of meer stellingen zijn overgeslagen of een sessie niet is afgemaakt. De sessies die in het geheel niet zijn ingevuld (i.e. rijen met 'NA') worden vanzelfsprekend ook niet meegenomen in de schatting. Let wel dat in 
tegenstelling tot de individuele netwerken niet de gehele persoon is verwijderd, maar alleen de sessies. Een extra exclusiecriterium is dat er van de deelnemers met meer dan 504 metingen alleen de eerste 504 worden meegenomen in de schatting. Ten slotte geldt dat alleen de deelnemers worden meegenomen die $95 \%$ of meer van de 504 datapunten hebben. Samenvattend, deelnemers die tussen 480 en 504 metingen hebben volbracht, zonder de overgeslagen en niet afgemaakte sessies zijn meegenomen in de analyse. De sample voor het netwerk bestond uit $\mathrm{N}=20$ deelnemers met een totaal van 9.912 datapunten. Bij het schatten van het mlVAR netwerk kwam verder naar voren dat de affect states Enthousiasme en Onzekerheid te weinig variantie vertoonden om mIVAR te laten werken. In de analyse zijn Enthousiasme en Onzekerheid om deze reden niet meegenomen.

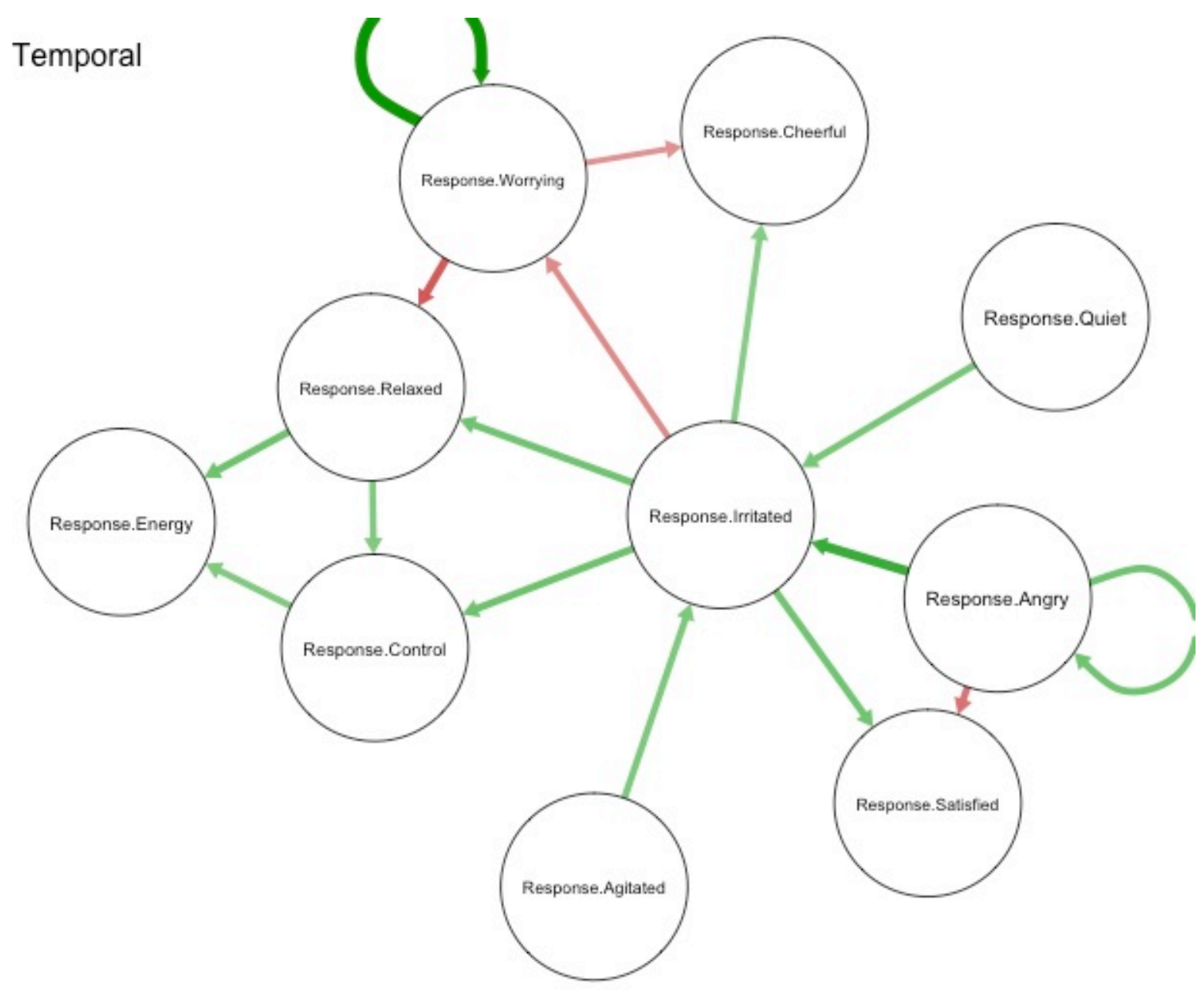

Figuur 5: Temporele netwerk van mIVAR analyse met 10 affect states 
In het temporele netwerk zijn de relaties af te lezen die plaatsvinden tussen verschillende windows of measurement. Allereerst vallen de twee feedback loops op van Zorgen Maken en Boosheid. Deze nodes kunnen dus beschouwd worden als zelfversterkend. Verder is er een op het oog erg centrale node Geïrriteerd die door veel andere nodes wordt beïnvloed en invloed heeft op andere nodes over verschillende windows of measurement. Controle ligt in het model niet erg centraal, en heeft alleen zwakke positieve invloed op Energie.

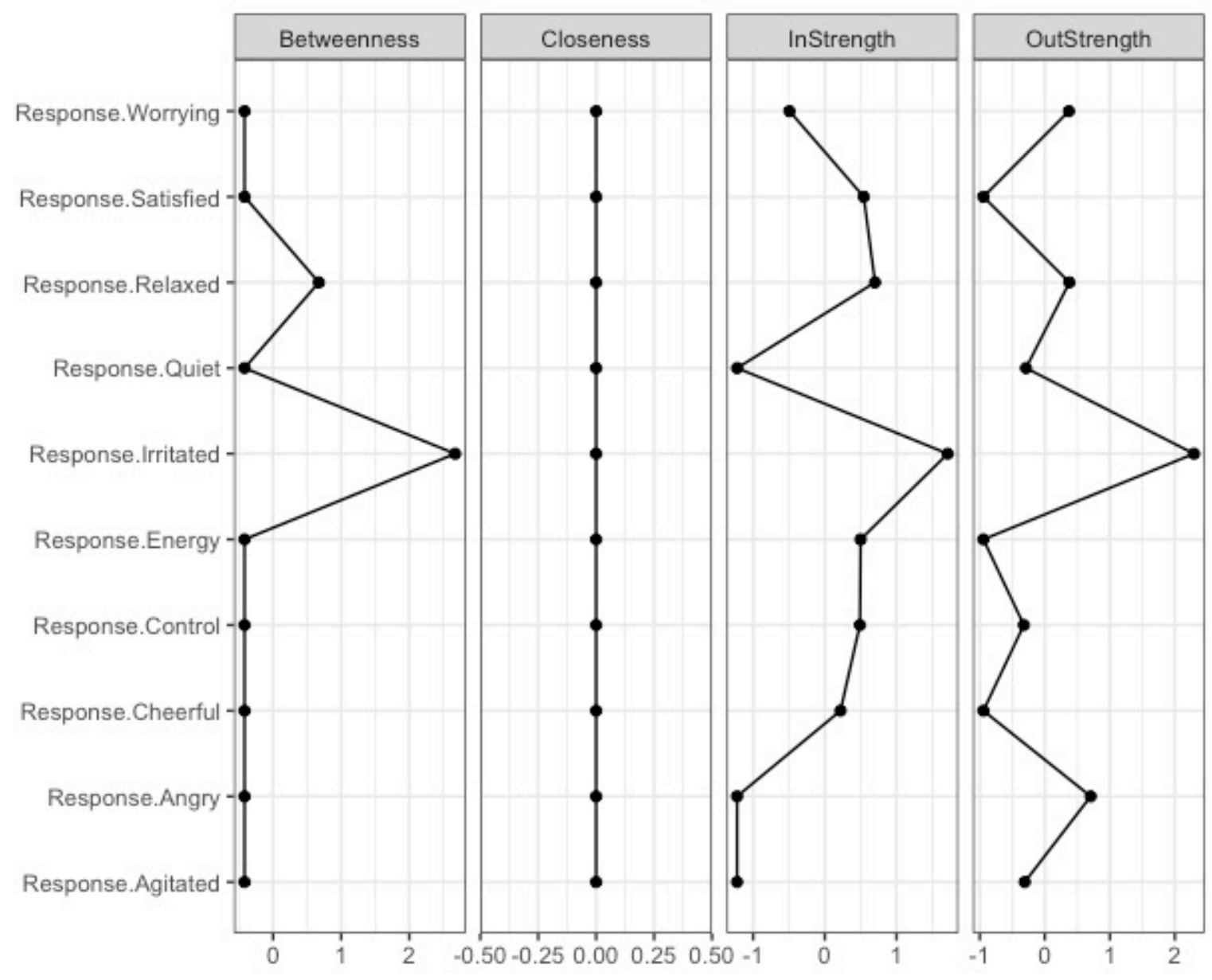

Figuur 6: Centraliteit van Temporeel netwerk

Uit de analyse van centraliteit (Figuur 6) is af te lezen, zoals ook al opviel in Figuur 5, dat Geïrriteerd de meest centrale node in het temporele netwerk is. Controle ligt in dit netwerk niet erg centraal en heeft dus geen hele sterke relaties met andere nodes over verschillende tijdsmetingen. 


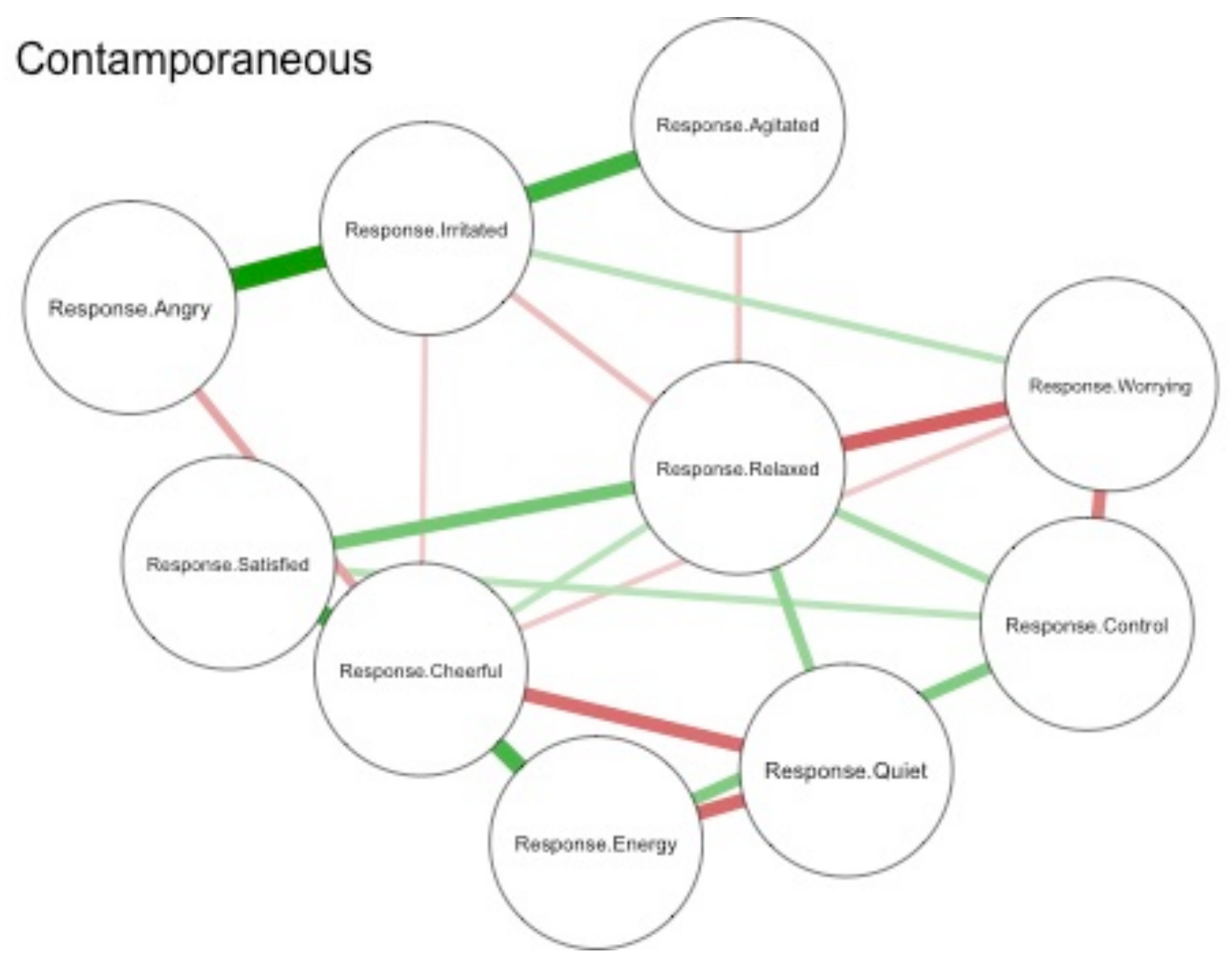

Figuur 7: Contemporaneous netwerk van mIVAR analyse met 10 affect states

Uit de residuele correlaties van het temporele netwerk wordt het contemporeneous netwerk geschat. Opvallend om te zien is dat Boosheid, Geïrriteerd en Geagiteerd allen vrij sterk met elkaar zijn verbonden. Deze affect states kunnen gezien worden als actief negatief en het is dus niet verbazend dat ze clusteren. Ook de clustering van Opgewektheid, Energie en Stil, waarbij Stil een negatief verband heeft met beide nodes is opvallend en goed te begrijpen. Controle heeft ten slotte ook interessante verbindingen. Het is te zien dat er positieve edges zijn met de meer passieve positieve affect states Ontspannen, Stil en Tevredenheid. Ook is er opnieuw, zoals uit het individuele netwerk van persoon 4 bleek, een negatieve relatie met Zorgen Maken, wat naar verwachting is. Wel moet er benoemd worden dat de negatieve relatie met overige negatieve affect states ontbreekt. 

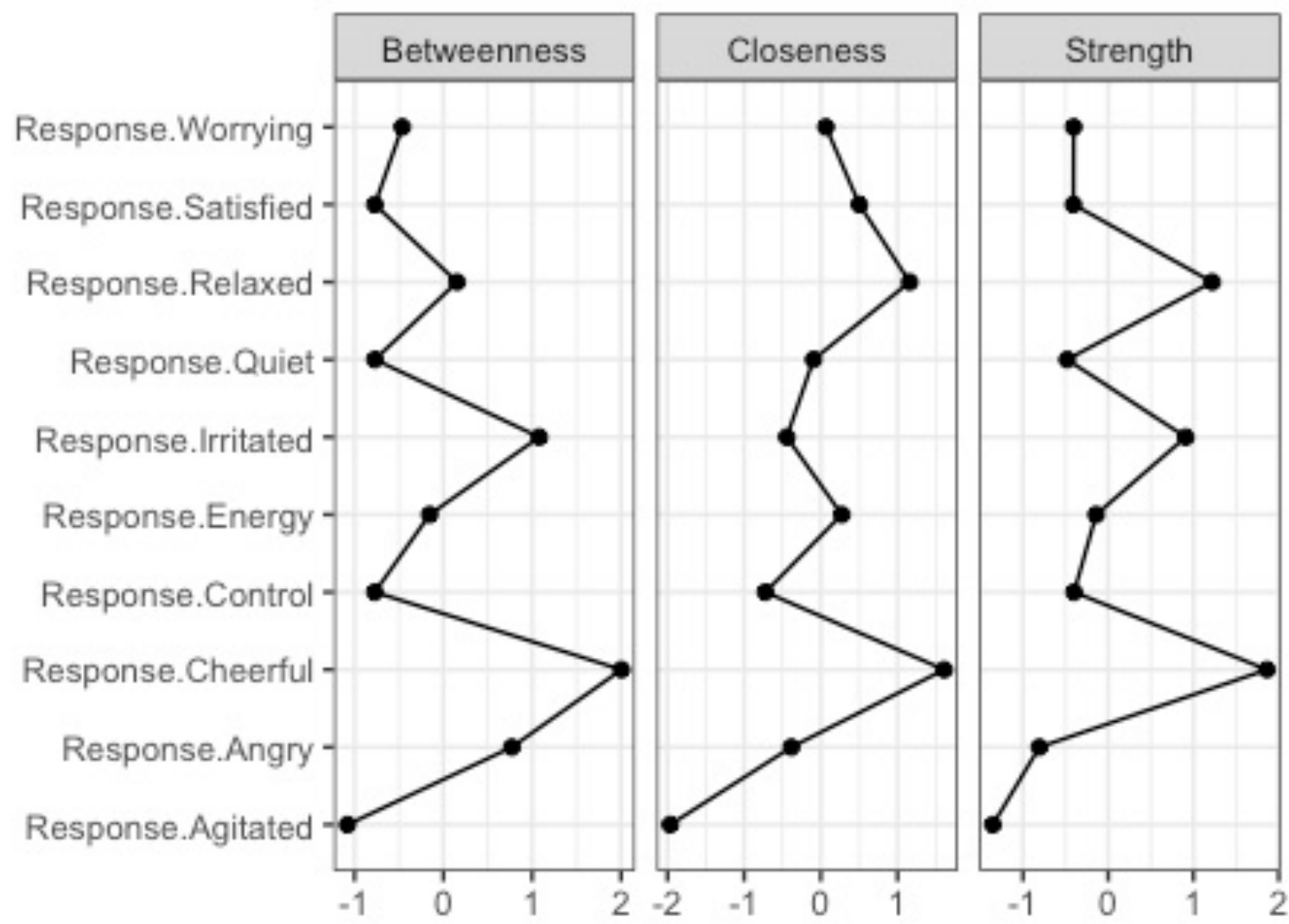

Figuur 8: Centraliteit van Contemporaneous netwerk

Uit de centraliteitsplot in Figuur 8 is duidelijk te zien dat in het contemporaneous netwerk Opgewektheid de meest centrale node is en dat Controle volgens de centrality measures geen belangrijke rol speelt in het netwerk.

Geconcludeerd kan worden dat uit de het temporele netwerk van de mIVAR analyse Geïrriteerd de belangrijkste affect state is en uit de contemporaneous analyse Opgewektheid. In vervolg onderzoek zouden deze nodes interessant zijn om te onderzoeken. Beide analyses geven geen duidelijke aanwijzing dat Controle een belangrijke affect state is.

\section{Discussie}

Door het ontbreken van een experimentele opzet bij het uitvoeren van een netwerkanalyse kan er, zoals in de inleiding kort genoemd werd, weinig gezegd worden over de oorzaken van resilience. Wel kan er door middel van de samenhang van Controle met de andere affect states, gekeken worden hoe resilience zich in de verschillende 
netwerken verhoudt. Deze resultaten zijn benoemd in de resultatensectie. Samenvattend werd duidelijk dat op basis van de geschatte individuele netwerken in dit onderzoek er weinig overeenkomsten zijn in de opbouw van de netwerken. Vanuit het perspectief van resilience bleek de operationaliserende factor 'Controle' in de verschillende netwerken niet erg centraal te liggen. Allereerst was er tussen de individuele netwerk een groot verschil in de soorten verbindingen met de andere affect states en bleek uit de mIVAR analyse ook dat deze verbindingen niet erg sterk waren. De relatie met de passieve positieve affect states en met Zorgen Maken was echter wel opvallend en kan in de toekomst verder onderzocht worden.

Allereerst is het interessant om de relatie tussen Controle en Zorgen Maken kort te bespreken vanuit theoretisch perspectief. In het eerste individuele netwerk en in de mIVAR analyse viel op dat er een negatieve relatie was tussen deze twee knopen. Deze gevonden resultaten bevestigen de verwachting vanuit de 'Cognitive Appraisal Theory' dat door middel van een gevoel van controle, de ervaren stress verminderd wordt. Aangezien Zorgen Maken gerelateerd is aan het ervaren van stress is deze negatieve relatie tussen Zorgen Maken en Controle vanuit de 'Cognitive Appraisal Theory' logisch en versterken de resultaten de theorie en het effect van de internal locus of control.

Ten tweede werd er in de mIVAR analyse relaties gevonden tussen Controle en positieve passieve affect states. Ook in de individuele netwerken werden er positieve relaties gevonden tussen Controle en verschillende positieve affect states. Deze resultaten zijn in lijn met de eerder gevonden resultaten van het gevoel van controle en hun relatie met positieve affect states ( Warehime \& Woodson, 1971; Pannells \& Claxton; 2008).

Een aantal verwachte verbindingen met affect states ontbreekt echter wel in bepaalde netwerken. Zo vertoont Controle bij deelnemer twee en drie bijvoorbeeld geen enkele verbinding met de overige knopen. Een alternatieve verklaring voor deze verschillen is dat er door de survey geen vragen gesteld worden over de situatie waarin de persoon zich bevindt. Volgens de Cognitive Appraisal Theory wordt er een inschatting gemaakt over een gebeurtenis (namelijk is deze controleerbaar of niet) en aan de hand daarvan door middel van de secondary appraisal een manier van coping gekozen. In veel 
gevallen kan een gevoel van controle ervoor zorgen dat een situatie als uitdaging wordt gezien en wordt een problem focussed manier van coping gebruikt. Hoewel het zoeken naar een oplossing een goede manier van omgaan met een situatie lijkt te zijn, is dit niet in alle gevallen zo. Uit het artikel van Folkman (1984) blijkt dat het gevoel van controle ook tot negatieve emoties kan leiden als dit gevoel niet terecht is. Dit heeft te maken met de aard van een situatie. Als een situatie controleerbaar is en er door middel van de primary appraisal deze situatie gezien wordt als een uitdaging is de juiste manier van omgaan met deze situatie om een problem focussed manier van coping te gebruiken. Deze manier wordt sneller gevonden als men het gevoel heeft dat er hoge controle is over de situatie. Stel dat nu een situatie oncontroleerbaar is, dan is het belangrijk om een andere manier van coping te gebruiken: emotion focussed coping. Bij deze manier wordt er met een stressvolle situatie omgegaan door middel van het reguleren van emoties in tegenstelling tot het zoeken naar een praktische oplossing (Folkman, 1984). Als de situatie nu ten onrechte wordt ingeschat als controleerbaar, kan dit een onjuiste manier van coping induceren, waardoor de positieve invloed van Controle verdwijnt. Vanuit theoretisch oogpunt zouden de ontbrekende Controle en andere affect states (deelnemer twee en drie), verklaard kunnen worden door een gebrek aan kennis van de context, waarbij een oncontroleerbare situatie ten onrechte is ingeschat als controleerbaar en dus niet de positieve relatie met positieve affect states laat zien. Door deze verklaring is Controle wellicht een te simpele weergave van het construct resilience. In vervolgonderzoek is het van belang om de focus te richten op de juistheid van de inschatting van een situatie en dan te kijken hoe Controle in verhouding staat tot andere affect states, waardoor Controle een betere representatie is van resilience. Aangezien het huidige onderzoek driemaal daags om een respons vroeg en er veel momenten zijn waarop zich geen specifieke situatie voordeed, was het in de huidige opzet van het onderzoek moeilijk om een dergelijke inschatting te vragen.

Daarnaast is er een ander punt over de operationalisatie Controle. Zoals te lezen is in de inleiding is de keuze gemaakt om een gevoel van controle te gebruiken als operationalisatie van resilience. Deze keuze was gebaseerd op het construct hardiness dat uit verschillende onderzoeken en artikelen een grote correlatie met resilience vertoont (Kobasa, Maddi \& Kahn, 1982; aangehaald in Bonanno, 2004; Steinhardt \& Dolbier, 2008). Verder bleek uit een factoranalyse dat hardiness was opgebouwd uit drie 
componenten, te weten: toewijding, controle en uitdaging (Kobasa, 1979; Maddi \& Kobasa, 1984; aangehaald in Maddi et al., 2012). Als onderbouwde keuze is vervolgens gekozen om Controle als component te gebruiken voor het meten van resilience. Uit het huidige onderzoek is echter gebleken dat de factor Controle in mindere mate in verband stond met bepaalde affect states dan van tevoren werd verwacht. Zoals in het vorige discussiepunt werd benoemd, is het mogelijk dat Controle afhankelijk is van de inschatting van de aard van de situatie. Een andere mogelijkheid is dat de component Controle te spaarzaam is voor het meten van hardiness die op zijn beurt een hoge correlatie vertoont met resilience. Misschien is het de combinatie van de drie componenten van hardiness tesamen die zorgt voor de sterke samenhang met resilience en is het niet mogelijk om deze samenhang te meten met één component. In vervolgonderzoek is het mogelijk om resilience te operationaliseren als hardiness met alle drie de bijbehorende componenten, om te kijken of deze factor wel aan de verwachte verbanden voldoet.

Een methodologisch punt betreft de databehandeling van het huidige onderzoek. Allereerst waren er in de ruwe dataset veel verschillende vormen van missing data. Zo waren er bepaalde sessies waar vragen zijn overgeslagen, sessies die niet waren ingevuld en sessies die voor wat voor reden dan ook halverwege zijn afgebroken. Voor de individuele netwerken is er de keuze gemaakt om van de personen die een van deze missings hadden geen netwerk te schatten, waardoor er uiteindelijk 5 van de mogelijke 31 individuele netwerken zijn geschat. Deze vrij rigoureuze keuze is gemaakt vanuit een oogpunt waarin het zeker moest zijn dat de data in een temporeel individueel netwerk hun voorspellende waarde behielden. Aan de andere kant zijn er op deze manier echter veel datapunten niet behandeld en heeft het onderzoek door het schatten van een beperkt aantal netwerken aan enige kracht ingeboet. In toekomstig onderzoek is het een goed startpunt om duidelijker voor ogen te hebben welke soorten missings er kunnen zijn en wat de mogelijke oplossing hiervoor kan zijn, zonder deze deelnemers direct uit te sluiten van een individueel netwerk. Een suggestie hierbij is bijvoorbeeld om een vergoeding te geven, waardoor deelnemers gemotiveerder zijn om alles in te vullen of en van te voren beter duidelijk te maken dat het overslaan of niet afmaken van vragen of hele sessies een nadelig gevolg heeft op de bruikbaarheid van de data. 
Een ander punt betreffend de databehandeling kwam vanuit feedback van de deelnemers. In de applicatie bleek het mogelijk om tot twee measurements of time terug in te vullen (in de avond was het bijvoorbeeld nog mogelijk om de middag- en de ochtendsessie in te vullen). De voorspellende waarde van temporele netwerken was niet erg sterk, aangezien een echt temporeel effect plaatsvindt in een kwestie van seconden (Epskamp et al., 2017), terwijl het gemeten temporele effect met de measurements of time in het huidige onderzoek uren betreft. Als nu ook blijkt dat er meerdere metingen tegelijk ingevuld kunnen worden, verliest de voorspellende kracht van de temporele netwerken nog meer aan kracht. Het is belangrijk om in het vervolg deze mogelijkheid uit te schakelen of gebruik te maken van een andere applicatie waarbij dit niet mogelijk is, om te zorgen dat elke meting ook daadwerkelijk plaatsvond op het juiste moment.

Zoals uit de eerste twee theoretische discussiepunten blijkt, valt er iets te zeggen over de operationalisatie Controle. Wellicht is Controle enigszins makkelijk, door het ontbreken van context van een situatie, en is Controle te spaarzaam. Wel is het goed om in gedachte te houden dat in veel jaren onderzoek resilience een construct is gebleken dat veel facetten kent (Werner, 1995), die op hun beurt ook nog verschillen per individu (Luthar et al., 2000). Daarbij was het in het huidige onderzoek noodzakelijk dat de vraag paste in een korte survey en is deze operationalisatie om deze praktische beperking vrij sterk. Hoewel uit de methodologische discussiepunten blijkt dat het onderzoek aan enige kracht heeft ingeboet, is het vooral belangrijk om de waarde van het onderzoek niet te onderschatten. Er zijn vijf individuele netwerken geschat zonder missing data, waarbij alle verbanden die bij de verschillende individuen gevonden zijn, betekenis hebben voor één individu, precies zoals een persoonlijk netwerkmodel bedoeld is. Zo faciliteert het model op een juiste manier de persoonlijke aandacht die het construct resilience nodig heeft. Daarnaast is er ook een multilevel model geschat, waarin 20 deelnemers zijn meegenomen met 9.912 datapunten. Dit netwerk kan altijd bekeken worden als er een netwerk wordt gevraagd dat is gebaseerd op meer datapunten.

Uit het onderzoek is geen sluitende definitie gekomen voor resilience en is het onderzoek naar dit construct nog zeker niet afgesloten. Wel is door middel van het gebruik van netwerken de aard van resilience onderzocht op de persoonsgeörienteerde, en over tijd fluctuerende manier die het construct verlangt. Met de theoretische en 
methodologische suggesties, kan gezegd worden dat het gebruik van een netwerk analyse in vervolgonderzoek veelbelovend kan zijn als oriëntatie naar persoonsgebonden resilience-factoren. 


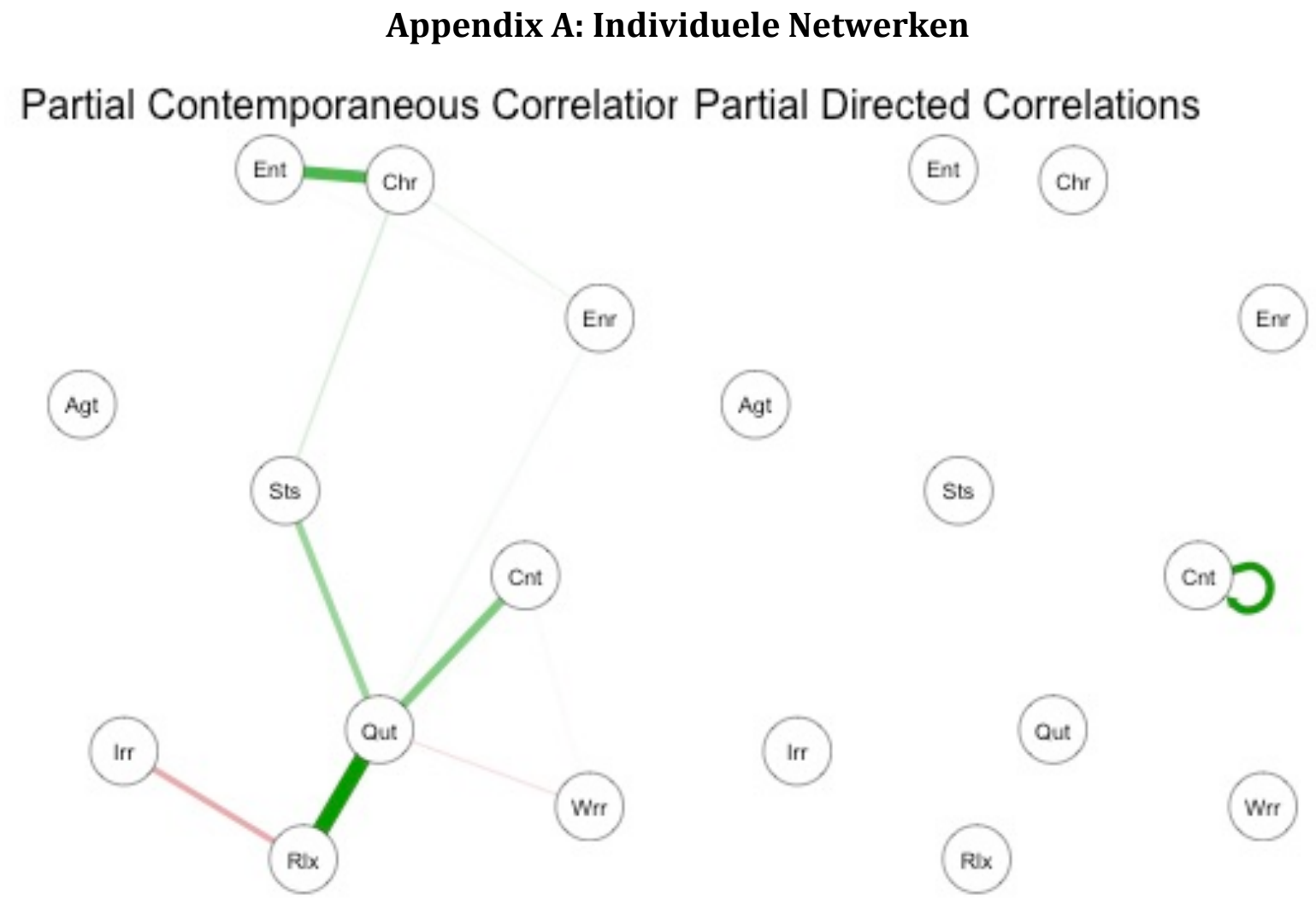

Deelnemer 1:

In dit persoonlijke netwerk zijn de knopen Onzeker en Boos verwijderd omdat deze beide te weinig variantie vertoonden. In het temporele netwerk is er feedback-loop van Controle zichtbaar. Over de residuele correlatie is het contemporaneous netwerk geschat. Controle vertoont een positieve verbinding met de knoop Stil. Sterke positieve verbanden zijn te zien tussen Relaxt en Stil en tussen Enthousiast en Opgewekt. Er is een licht negatief verband te zien tussen Geïrriteerd en Relaxt. Stil heeft de meeste (5) verbindingen. 

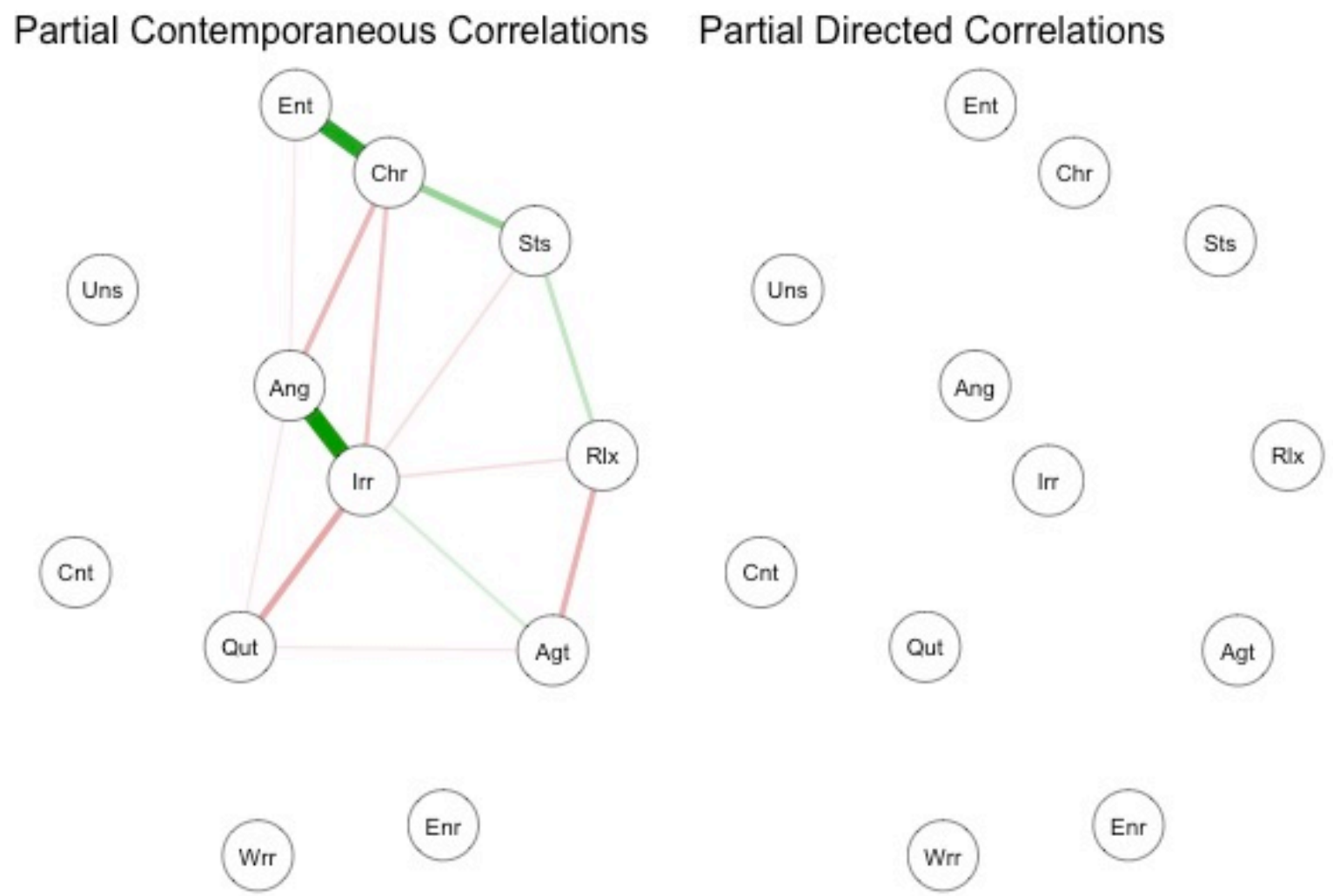

Deelnemer 2:

In het temporele netwerk zijn geen verbindingen zichtbaar. Over de residuele correlatie is het contemporaneous netwerk geschat. Controle vertoont geen verbindingen met de overige knopen in het netwerk. Sterke positieve verbanden zijn te zien tussen Boosheid en Irritatie en tussen Opgewektheid en Enthousiasme. Irritatie heeft de meeste (6) verbindingen. 


\section{Partial Contemporaneous Correlations}
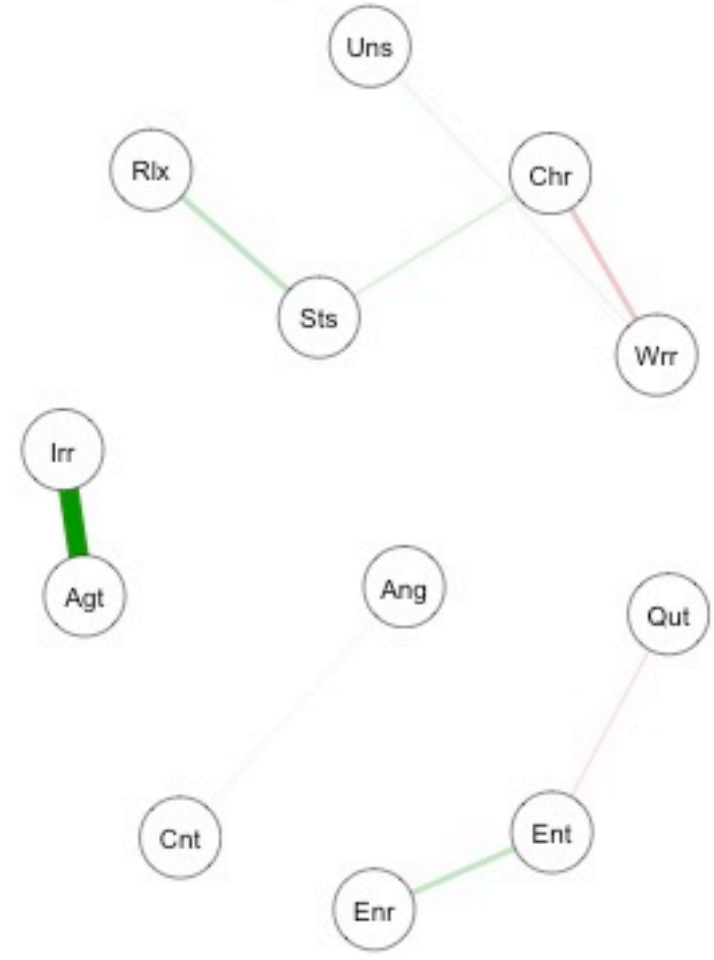

Partial Directed Correlations

Uns

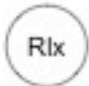

Chr

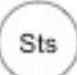

Ang

Qut
IrT

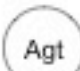

Agt

Cnt

Deelnemer 3:

In het temporele netwerk zijn geen verbindingen zichtbaar. Over de residuele correlatie is het contemporaneous netwerk geschat. Controle vertoont geen verbindingen met de overige knopen in het netwerk. Er is een sterk positief verband te zien tussen Irritatie en Geagiteerd. Er is geen duidelijke centrale knoop in dit netwerk, er zijn meerdere knopen met 2 verbindingen. 


\section{Partial Contemporaneous Correlations}

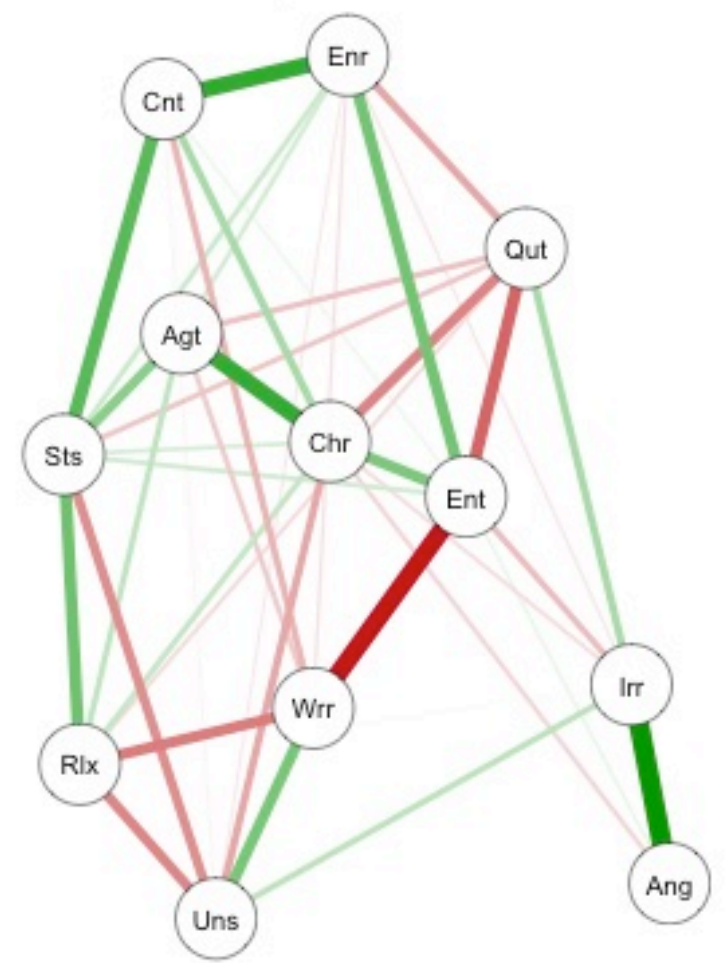

Partial Directed Correlations

(Cnt

Enr

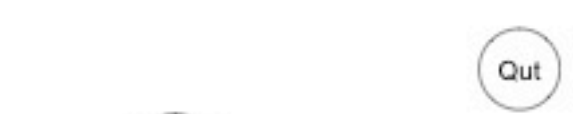

Agt
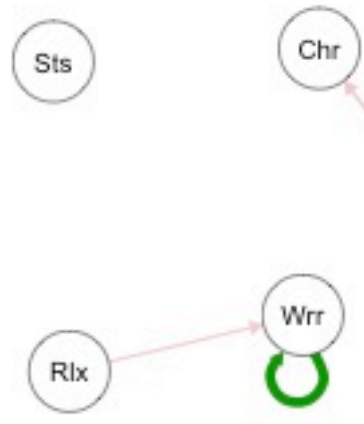

Irr

Ang

Deelnemer 4:

Dit netwerk is besproken in de lopende tekst. 


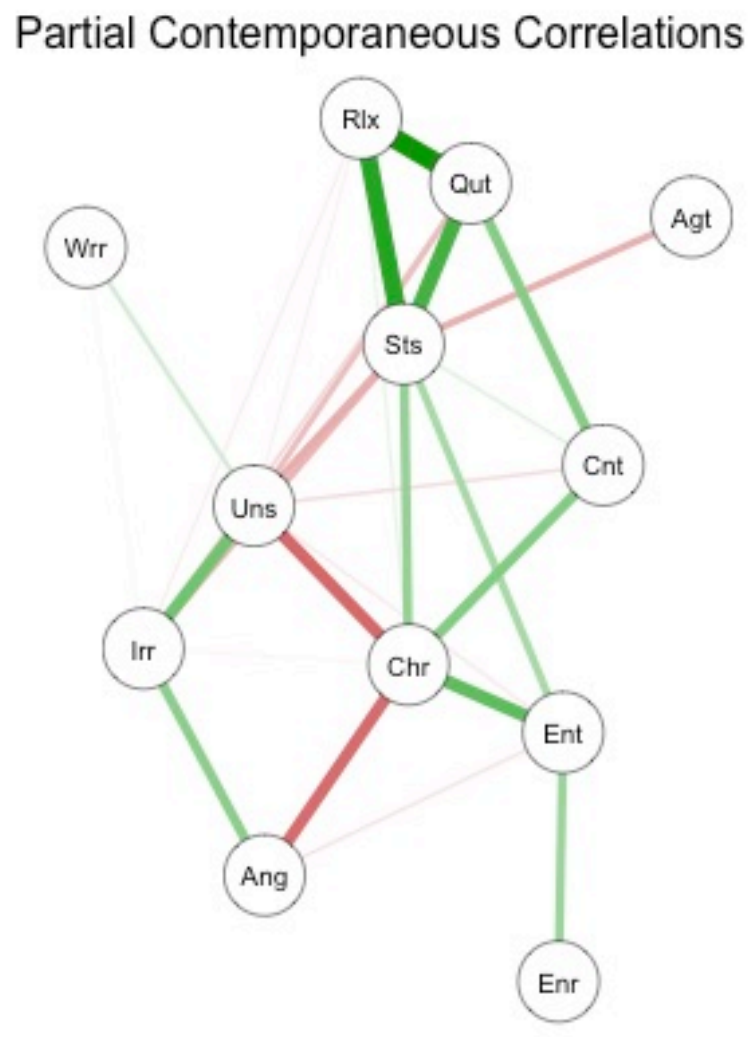

Partial Directed Correlations

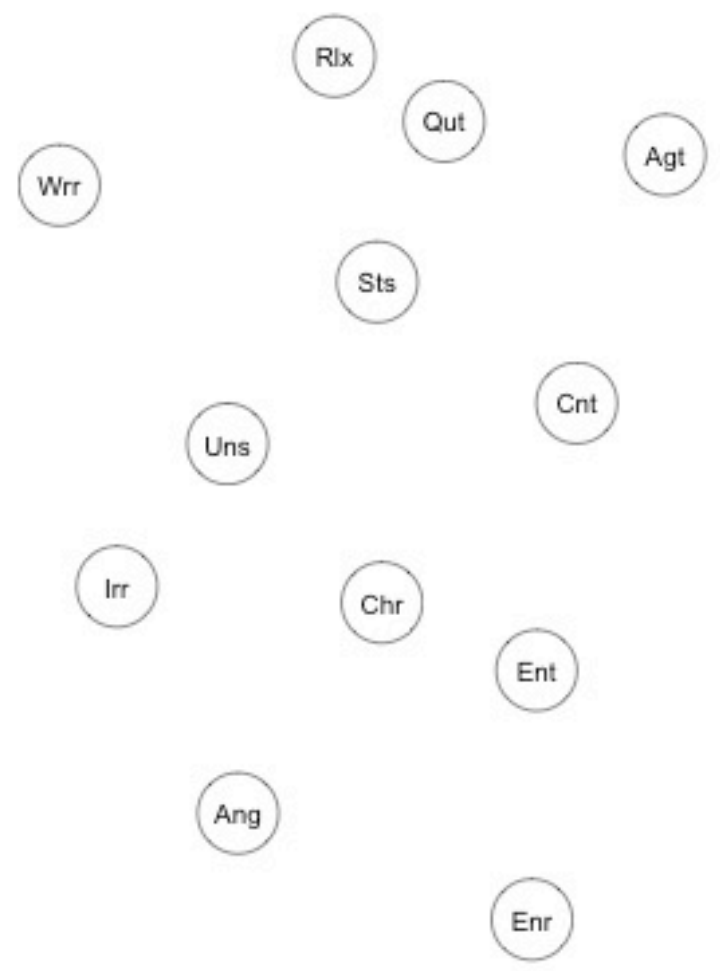

Deelnemer 5:

Dit netwerk is besproken in de lopende tekst. 


\section{Appendix B: Survey}

"Worrying": I am worrying.

"Satisfied": I am satisfied.

"Cheerful": I am cheerful.

"Energy": I feel full of energy.

"Unsure": I feel unsure.

"NotWell": I don't feel well.

"Relaxed": I am relaxed.

"Agitated": I feel agitated.

"AngryIrr": I am angry or irritated.

"Quiet": I feel quiet.

"Enthus": I feel enthusiastic.

"Control": I feel in control 


\section{Appendix C}

\section{Consent Form}

Date:

Dear

(please fill in your name and surname),

This form relates to information presented on the previous screen that described the current research study. By selecting "Yes" below, you declare that you understand the nature and methods of this study as described in the information letter. In addition, you declare that:

- I am 18 or older

- I have read and understood the information letter

- I agree to participate in this study and I agree with the use of the data that are collected

- I reserve the right to withdraw my participation from the study at any moment without providing any reason.

Should you have questions about the study you would like answered before proceeding or at any other time, please contact the research team (resiliencefactors2018@gmail.com) or the researcher responsible for overseeing this study, Gaby Lunansky

(g.lunansky@uva.nl).Formal complaints about this study can be addressed to the Ethics

Review Board; G. Valk (g.h.valk@uva.nl)

Yes, I understand the nature and methods of this study and am choosing to participate

\section{Personal information:}

Sex/gender (please circle the relevant option): male / female / other

Age:

Signature: 


\section{Appendix D: Literatuurlijst}

Affect States, Wikipedia, z.j. https://en.wikipedia.org/wiki/Affect_(psychology)

Baker, J. P., \& Berenbaum, H. (2007). Emotional approach and problem-focused coping: A comparison of potentially adaptive strategies. Cognition and Emotion, 21(1), 95118.

Bonanno, G. A. (2004). Loss, trauma, and human resilience: have we underestimated the human capacity to thrive after extremely aversive events? American psychologist, 59(1), 20.

Borsboom, D., \& Cramer, A. O. (2013). Network analysis: an integrative approach to the structure of psychopathology. Annual review of clinical psychology, 9, 91-121.

Collishaw, S., Pickles, A., Messer, J., Rutter, M., Shearer, C., \& Maughan, B. (2007). Resilience to adult psychopathology following childhood maltreatment: Evidence from a community sample. Child abuse \& neglect, 31(3), 211-229.

Connor, K. M., \& Davidson, J. R. (2003). Development of a new resilience scale: The Connor-Davidson resilience scale (CD-RISC). Depression and anxiety, 18(2), 7682.

Epskamp, S., van Borkulo, C. D., van der Veen, D. C., Servaas, M. N., Isvoranu, A. M., Riese, H., \& Cramer, A. O. (2017). Personalized network modeling in psychopathology: The importance of contemporaneous and temporal connections. Clinical Psychological Science, 2167702617744325.

Folkman, S. (1984). Personal control and stress and coping processes: A theoretical analysis. Journal of personality and social psychology, 46(4), 839.

Fried, E. I., Epskamp, S., Nesse, R. M., Tuerlinckx, F., \& Borsboom, D. (2016). What are'good'depression symptoms? Comparing the centrality of DSM and non-DSM 
symptoms of depression in a network analysis. Journal of Affective Disorders, 189, 314-320.

Johnson, J., \& Wood, A. M. (2017). Integrating positive and clinical psychology: Viewing human functioning as continua from positive to negative can benefit clinical assessment, interventions and understandings of resilience. Cognitive Therapy and Research, 41(3), 335-349.

Kobasa SC. Stressful life events, personality, and health: an inquiry into hardiness. $J$ Pers Soc Psychol. 1979 ;37: 1-11.

Luthar, S. S., Cicchetti, D., \& Becker, B. (2000). The construct of resilience: A critical evaluation and guidelines for future work. Child development, 71(3), 543-562.

Maddi, S. R., Khoshaba, D. M., Jensen, K., Carter, E., Lu, J. L., \& Harvey, R. H. (2002). Hardiness training for high-risk undergraduates. NACADA Journal, 22(1), 4555.

Masten, A. S. (1994). Resilience in individual development: Successful adaptation despite risk and adversity.

Opsahl, T., Agneessens, F., \& Skvoretz, J. (2010). Node centrality in weighted networks: Generalizing degree and shortest paths. Social networks, 32(3), 245-251.

Pannells, T. C., \& Claxton, A. F. (2008). Happiness, creative ideation, and locus of control. Creativity research journal, 20(1), 67-71.

Sandler, I. N., \& Lakey, B. (1982). Locus of control as a stress moderator: The role of control perceptions and social support. American Journal of Community Psychology, 10(1), 65-80. 
Steinhardt, M., \& Dolbier, C. (2008). Evaluation of a resilience intervention to enhance coping strategies and protective factors and decrease symptomatology. Journal of American college health, 56(4), 445-453.

Szabó, M. (2011). The emotional experience associated with worrying: anxiety, depression, or stress?. Anxiety, Stress, \& Coping, 24(1), 91-105.

Warehime, R. G., \& Woodson, S. (1971). Locus of control and immediate affect states. Journal of Clinical Psychology, 27(4), 443-444.

Werner, E. E. (1995). Resilience in development. Current directions in psychological science, $4(3), 81-84$.

Wolf, E. J., Miller, M. W., Sullivan, D. R., Amstadter, A. B., Mitchell, K. S., Goldberg, J., \& Magruder, K. M. (2018). A classical twin study of PTSD symptoms and resilience: evidence for a single spectrum of vulnerability to traumatic stress. Depression and anxiety, 35(2), 132-139. 


\title{
Appendix E: R-Code
}

\section{Uiteindelijke_Code.R}

\author{
daanblankenstijn
}

Wed Jun 27 12:28:00 2018

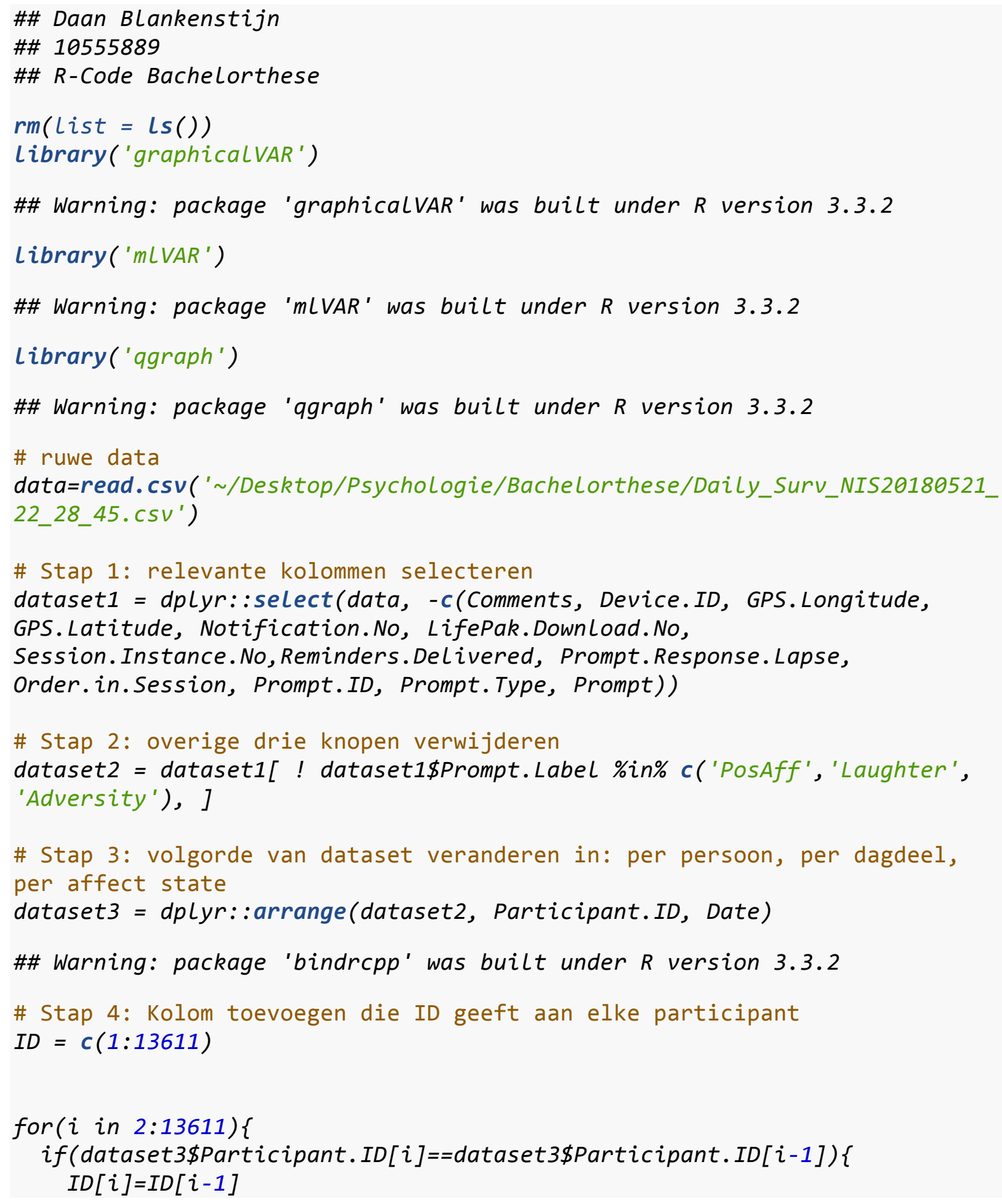




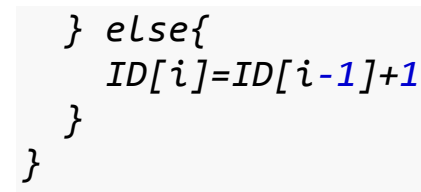




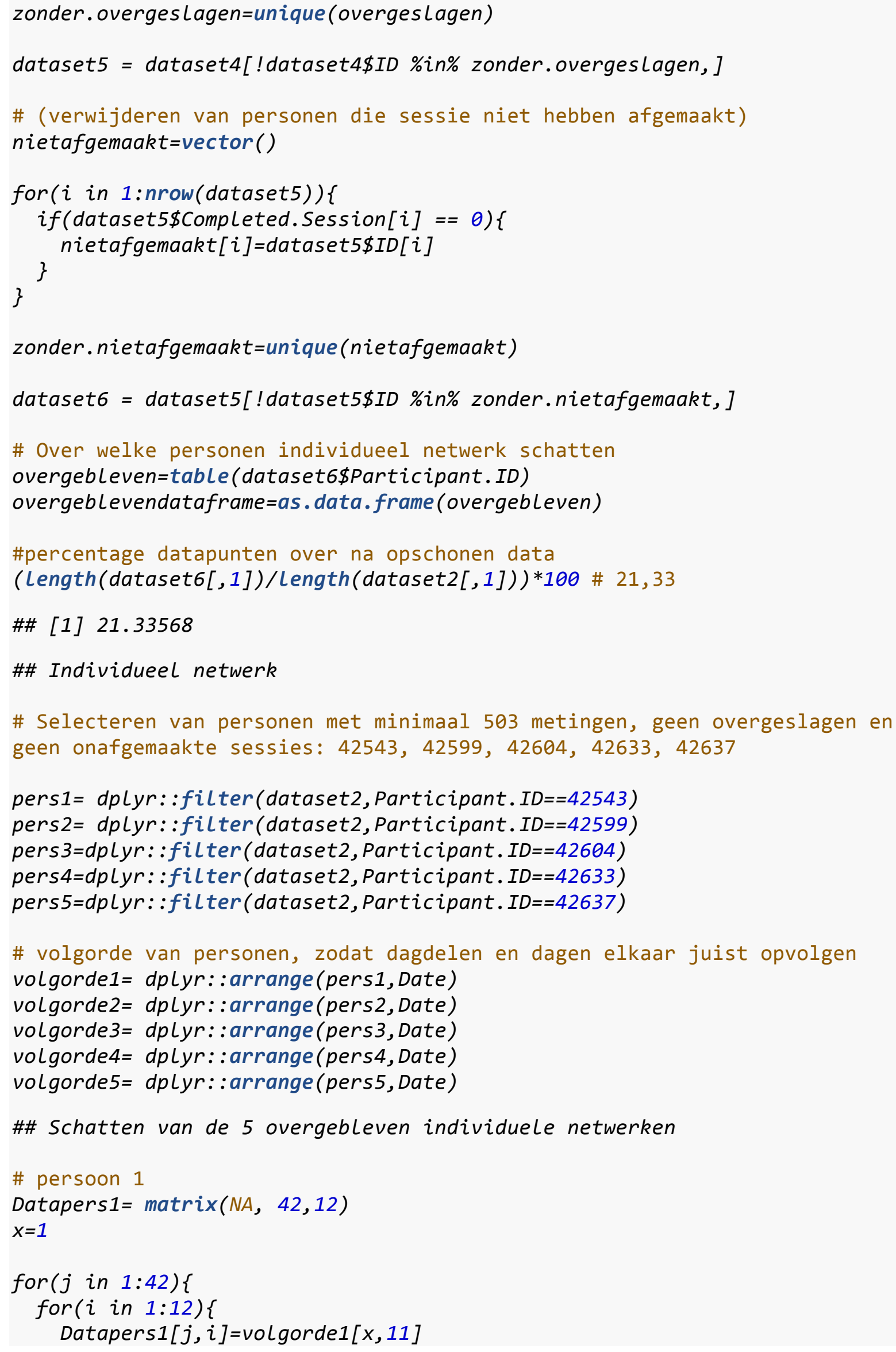


Datapers1 $[j, i]=\operatorname{Datapers1}[j, i]-2$ \#-2: als dit niet wordt gedaan komen de waardes te hoog uit

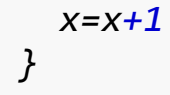

\section{Datapers1}

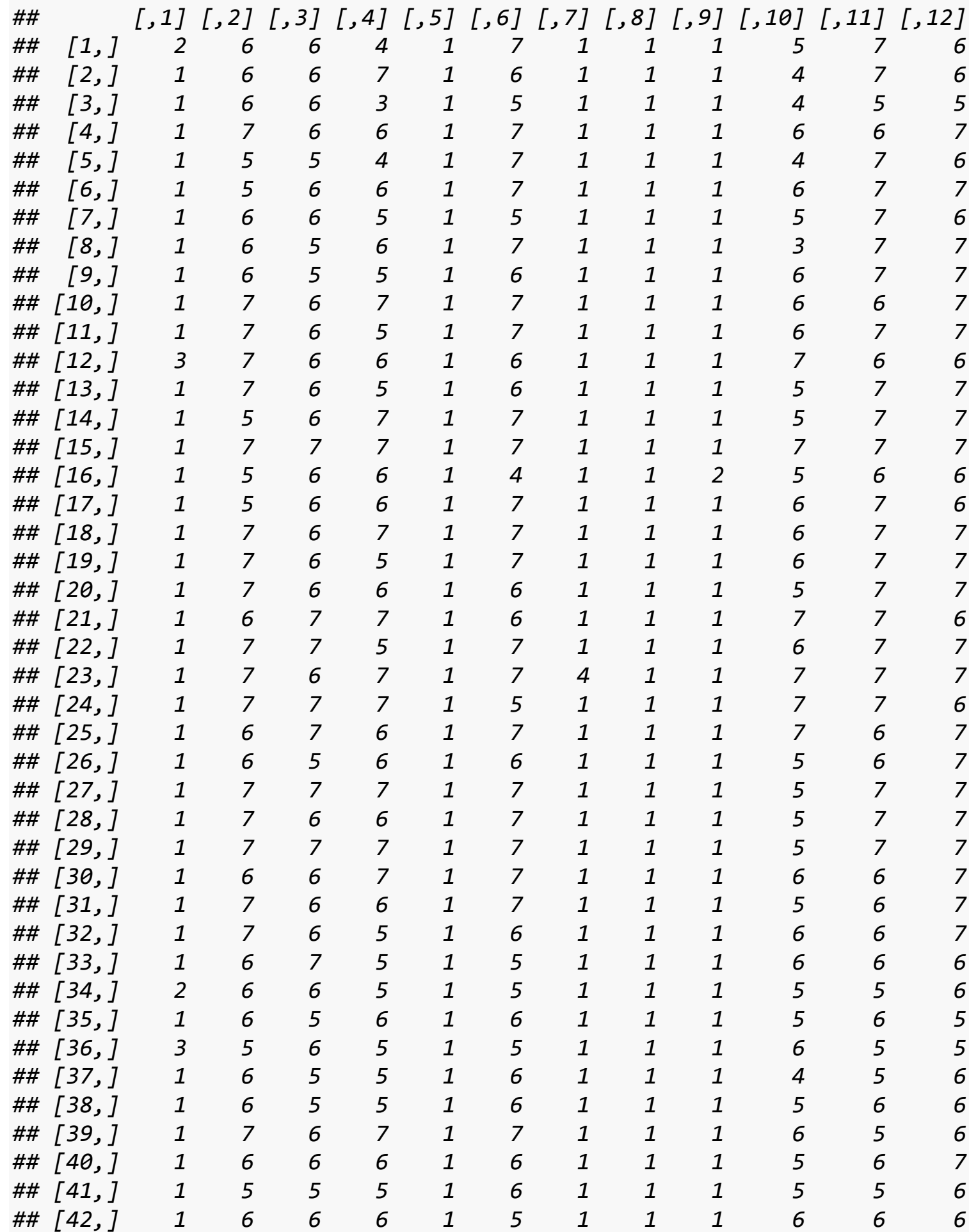

persoon1 = as.data $\cdot$ frame (Datapers1)

colnames(persoon1) = c("Worrying", "Satisfied", "CheerfuL", "Energy", 
"Unsure", "Relaxed", "Agitated", "Angry", "Irritated", "Enthusiast",
"Control", "Quiet")

persoon1\$Unsure=NULL \#variabele vertoont geen variantie, waardoor netwerk anders niet kan worden geschat

persoon1\$Angry=NULL \#variabele vertoont geen variantie, waardoor netwerk anders niet kan worden geschat

plot1 = graphicalVAR (persoon1, gamma=0, $n$ Lambda $=10$ )

\#\# 'summarise_each()' is deprecated.

\#\# Use 'summarise_all()', 'summarise_at()' or 'summarise_if()' instead.

\#\# To map 'funs' over a selection of variables, use 'summarise_at()'

\#\# 'mutate_each()' is deprecated.

\#\# Use 'mutate_all()', 'mutate_at()' or 'mutate_if()' instead.

\#\# To map 'funs' over a selection of variables, use 'mutate_at()'

graf.pcc1 $=p \operatorname{lot}\left(p \operatorname{lot} 1\right.$, layout $=$ 'spring', type $\left.={ }^{\prime} P C C^{\prime}\right)$

\#\# Warning in ggraph::qgraph(x\$PCC, Layout = Layout, $\ldots$, repulsion = \#\# repulsion): The following arguments are not documented and likely not \#\# arguments of ggraph and thus ignored: type

\#\# Warning in qgraph::qgraph(x\$PDC, Layout = Layout, ..., repulsion = \#\# repulsion, : The following arguments are not documented and likely not \#\# arguments of ggraph and thus ignored: type

graf.pcc1.1= plot (plot1, Layout= 'spring', type='temporal')

\#\# Warning in qgraph::qgraph(x\$PCC, Layout = Layout, ..., repulsion = \#\# repulsion): The following arguments are not documented and likely not \#\# arguments of qgraph and thus ignored: type

\#\# Warning in qgraph::qgraph $(x \$ P C C$, Layout $=$ Layout,... , repulsion $=$ \#\# repulsion): The following arguments are not documented and likely not \#\# arguments of ggraph and thus ignored: type 


\section{Partial Contemporaneous Correlı́ Partial Directed Correlations}

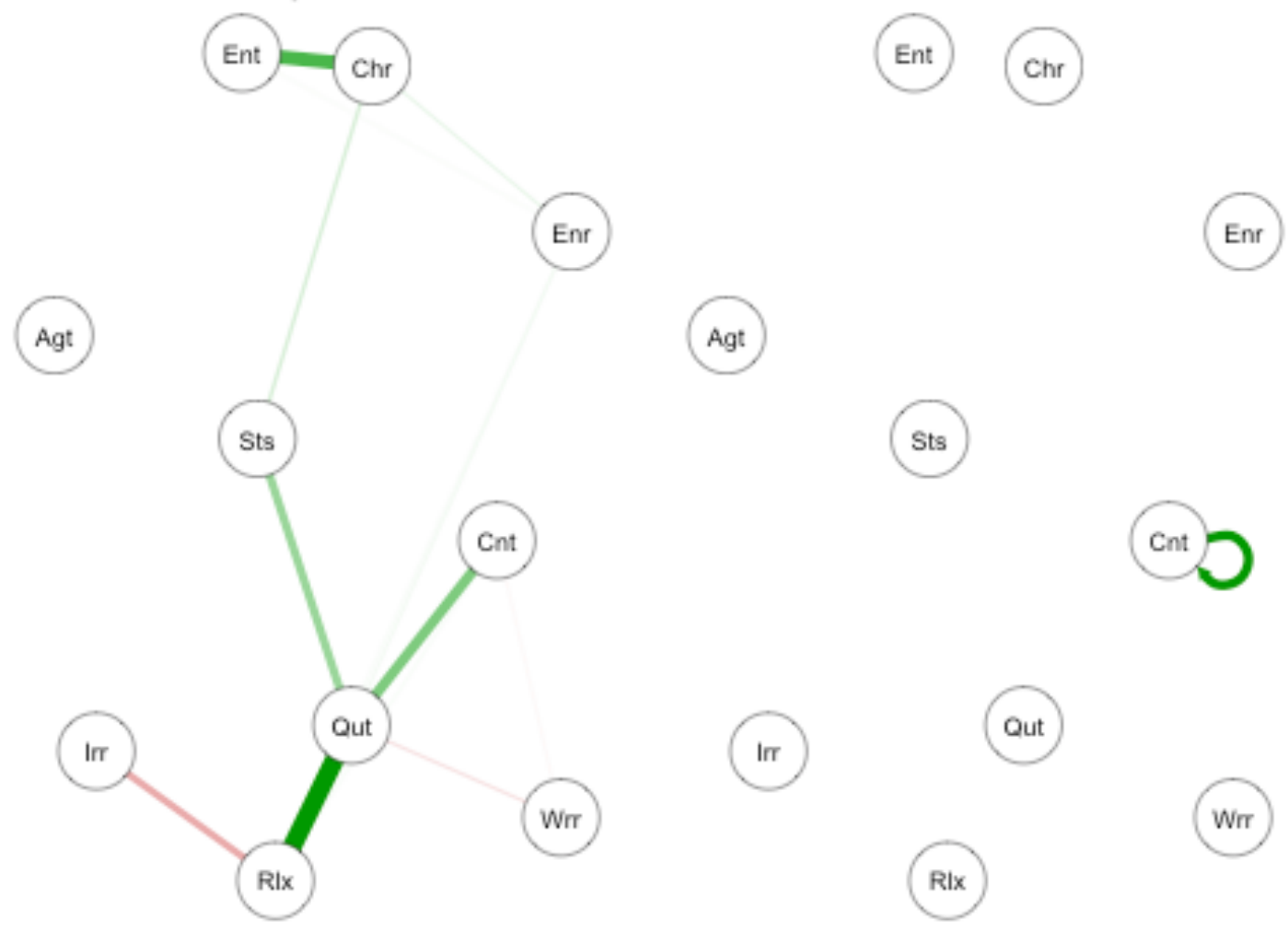

cen.pcc1 = centrality $($ graf.pcc1)

centralityPlot(getWmat(graf.pcc1))

\#\# Note: $z$-scores are shown on $x$-axis rather than raw centrality indices.

\#\# Warning: Removed 10 rows containing missing values (geom_path).

\#\# Warning: Removed 21 rows containing missing values (geom_point). 

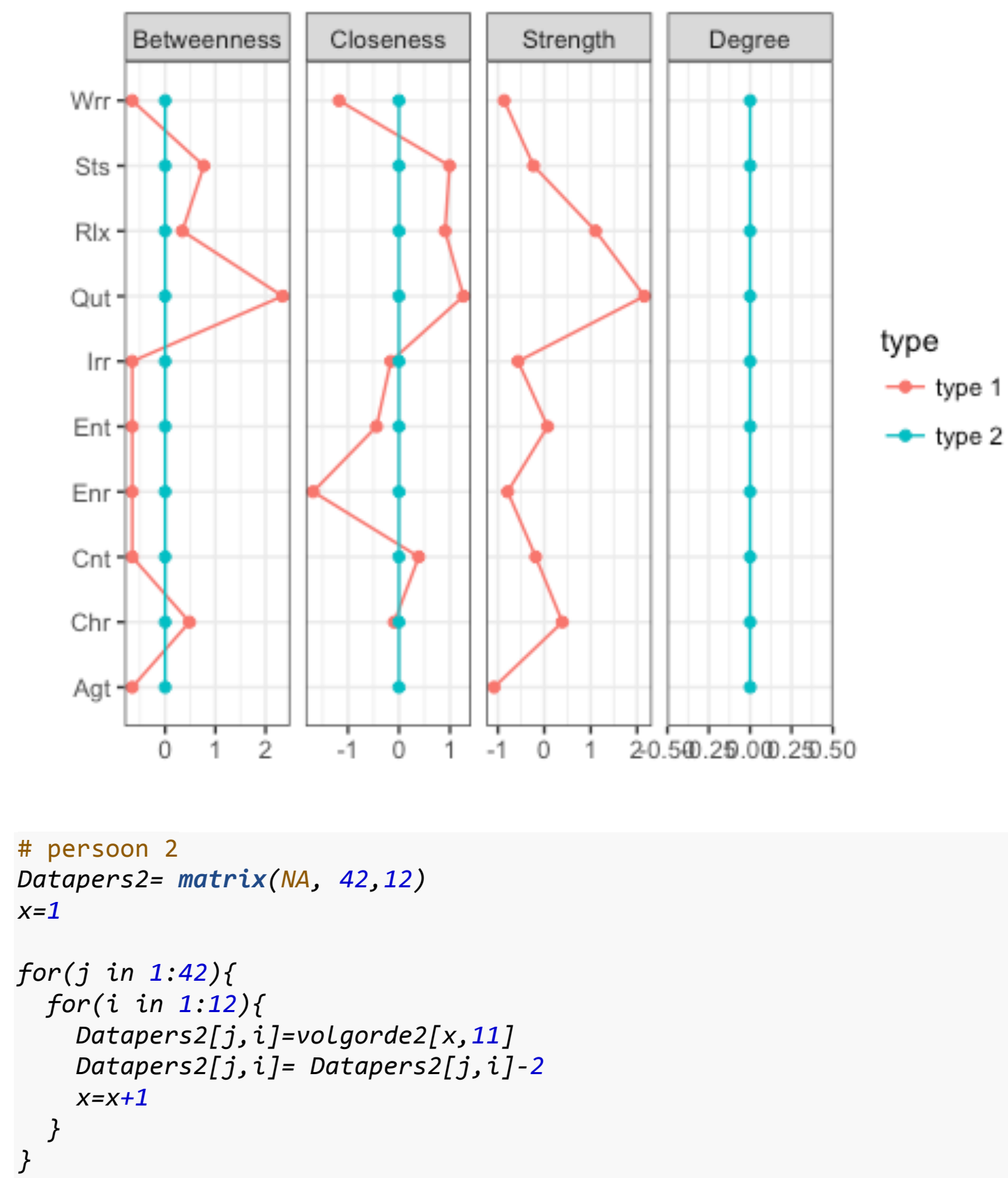


\begin{tabular}{|c|c|c|c|c|c|c|c|c|c|c|c|}
\hline$\# \#[13]$, & 4 & 5 & 5 & 4 & 2 & 6 & 2 & 1 & 1 & 4 & 2 \\
\hline$\# \#[14]$, & 7 & 4 & 3 & 3 & 4 & 4 & 4 & 3 & 2 & 2 & 2 \\
\hline$\# \#[15]$, & 4 & 3 & 3 & 4 & 2 & 2 & 5 & 5 & 6 & 5 & 4 \\
\hline$\# \#[16]$, & 4 & 5 & 4 & 3 & 2 & 5 & 2 & 2 & 1 & 3 & 2 \\
\hline$\# \#[17]$, & 2 & 4 & 5 & 5 & 4 & 3 & 3 & 1 & 1 & 5 & 2 \\
\hline$\# \#[18]$, & 3 & 4 & 4 & 3 & 1 & 4 & 4 & 3 & 4 & 3 & 4 \\
\hline$\# \#[19]$, & 3 & 3 & 5 & 5 & 2 & 3 & 2 & 1 & 2 & 5 & 4 \\
\hline$\# \#[20]$, & 4 & 2 & 1 & 4 & 4 & 2 & 5 & 5 & 5 & 3 & 4 \\
\hline$\# \#[21]$, & 2 & 4 & 6 & 5 & 1 & 4 & 3 & 5 & 2 & 7 & 3 \\
\hline$\# \#[22]$, & 3 & 6 & 5 & 5 & 1 & 5 & 4 & 3 & 2 & 5 & 2 \\
\hline$\# \#[23]$, & 3 & 3 & 4 & 4 & 2 & 4 & 2 & 2 & 1 & 4 & 3 \\
\hline$\# \#[24]$, & 4 & 1 & 1 & 4 & 1 & 1 & 5 & 7 & 7 & 1 & 7 \\
\hline$\# \#[25]$, & 3 & 4 & 3 & 2 & 1 & 5 & 3 & 2 & 1 & 3 & 2 \\
\hline$\# \#[26]$, & 4 & 4 & 4 & 4 & 1 & 4 & 4 & 4 & 4 & 4 & 4 \\
\hline$\# \#[27]$, & 2 & 5 & 5 & 4 & 1 & 4 & 1 & 2 & 2 & 5 & 4 \\
\hline$\# \#[28]$, & 2 & 5 & 5 & 2 & 1 & 5 & 3 & 2 & 2 & 4 & 4 \\
\hline$\# \#[29]$, & 3 & 2 & 6 & 5 & 1 & 4 & 3 & 3 & 3 & 6 & 4 \\
\hline$\# \#[30]$, & 2 & 5 & 5 & 5 & 1 & 5 & 2 & 2 & 1 & 5 & 3 \\
\hline$\# \#[31]$, & 3 & 3 & 2 & 2 & 4 & 3 & 5 & 5 & 5 & 2 & 3 \\
\hline$\# \#[32]$, & 1 & 1 & 1 & 7 & 1 & 7 & 1 & 7 & 7 & 1 & 7 \\
\hline$\# \#[33]$, & 2 & 2 & 1 & 4 & 1 & 1 & 4 & 7 & 7 & 1 & 7 \\
\hline$\# \#[34]$, & 2 & 6 & 4 & 3 & 1 & 6 & 2 & 2 & 2 & 3 & 5 \\
\hline$\# \#[35]$, & 4 & 5 & 5 & 5 & 1 & 4 & 4 & 3 & 3 & 5 & 5 \\
\hline$\# \#[36]$, & 1 & 4 & 5 & 4 & 1 & 4 & 2 & 5 & 5 & 4 & 6 \\
\hline$\# \#[37]$, & 2 & 5 & 5 & 4 & 2 & 5 & 2 & 3 & 4 & 5 & 4 \\
\hline$\# \#[38]$, & 2 & 5 & 6 & 5 & 2 & 4 & 4 & 3 & 4 & 5 & 4 \\
\hline$\# \#[39]$, & 2 & 2 & 4 & 4 & 1 & 4 & 2 & 2 & 1 & 4 & 4 \\
\hline$\# \#[40]$, & 3 & 4 & 2 & 3 & 2 & 5 & 4 & 4 & 3 & 3 & 4 \\
\hline$\# \#[41]$, & 2 & 5 & 5 & 5 & 1 & 5 & 3 & 2 & 1 & 5 & 5 \\
\hline$\# \#[42]$, & 2 & 2 & 3 & 4 & 2 & 3 & 4 & 2 & 4 & 4 & 4 \\
\hline
\end{tabular}

persoon2 = as.data. frame (Datapers2)

colnames(persoon2) = c("Worrying", "Satisfied", "Cheerful", "Energy", "Unsure", "Relaxed", "Agitated", "Angry", "Irritated", "Enthusiast", "Control", "Quiet")

plot2 $=$ graphicalVAR (persoon2, gamma=0, $n L a m b d a=10)$

\#\# 'summarise_each()' is deprecated.

\#\# Use 'summarise_all()', 'summarise_at()' or 'summarise_if()' instead. \#\# To map 'funs' over a selection of variables, use 'summarise_at()' \#\# 'mutate_each()' is deprecated.

\#\# Use 'mutate_all()', 'mutate_at()' or 'mutate_if()' instead.

\#\# To map 'funs' over a selection of variables, use 'mutate_at()'

graf.pcc2 $=p \operatorname{lot}(p$ Lot 2, Layout $=$ 'spring', 'PCC')

graf.pcc2.1= plot (plot2, Layout= 'spring', type='temporal')

\#\# Warning in qgraph::qgraph( $\$ \$ P C C$, Layout = Layout,.. , repulsion = \#\# repulsion): The following arguments are not documented and likely not \#\# arguments of ggraph and thus ignored: type 


\section{Partial Contemporaneous Correlı́}

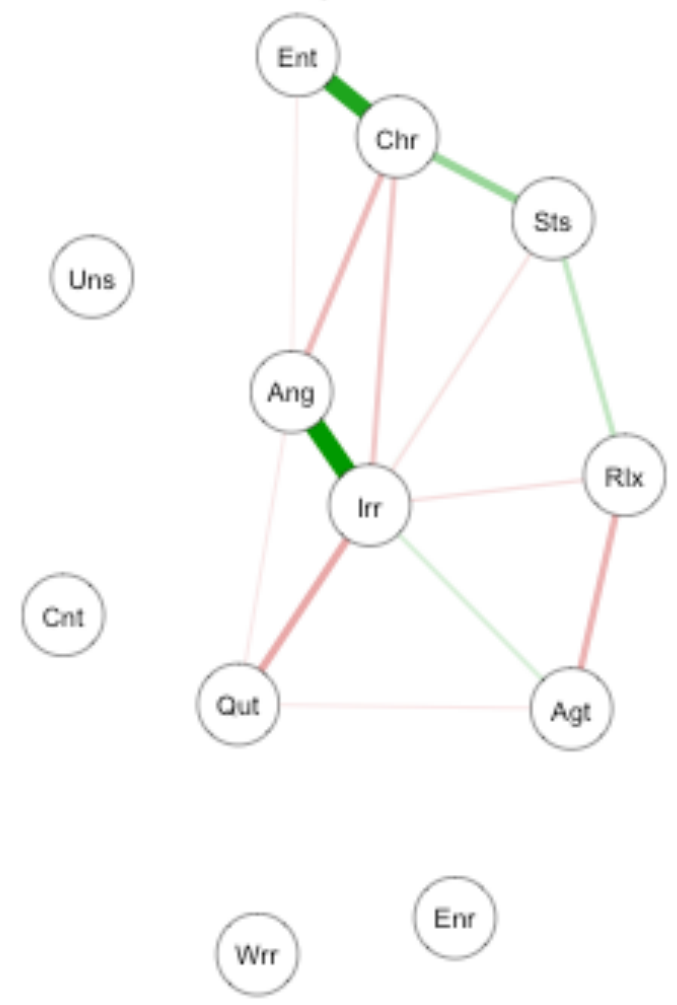

\#\# Warning in qgraph::qgraph $(x \$ P D C$, Layout $=$ Layout,.. , repulsion = \#\# repulsion, : The following arguments are not documented and likely not \#\# arguments of ggraph and thus ignored: type 


\section{Partial Contemporaneous Correlı́ Partial Directed Correlations}

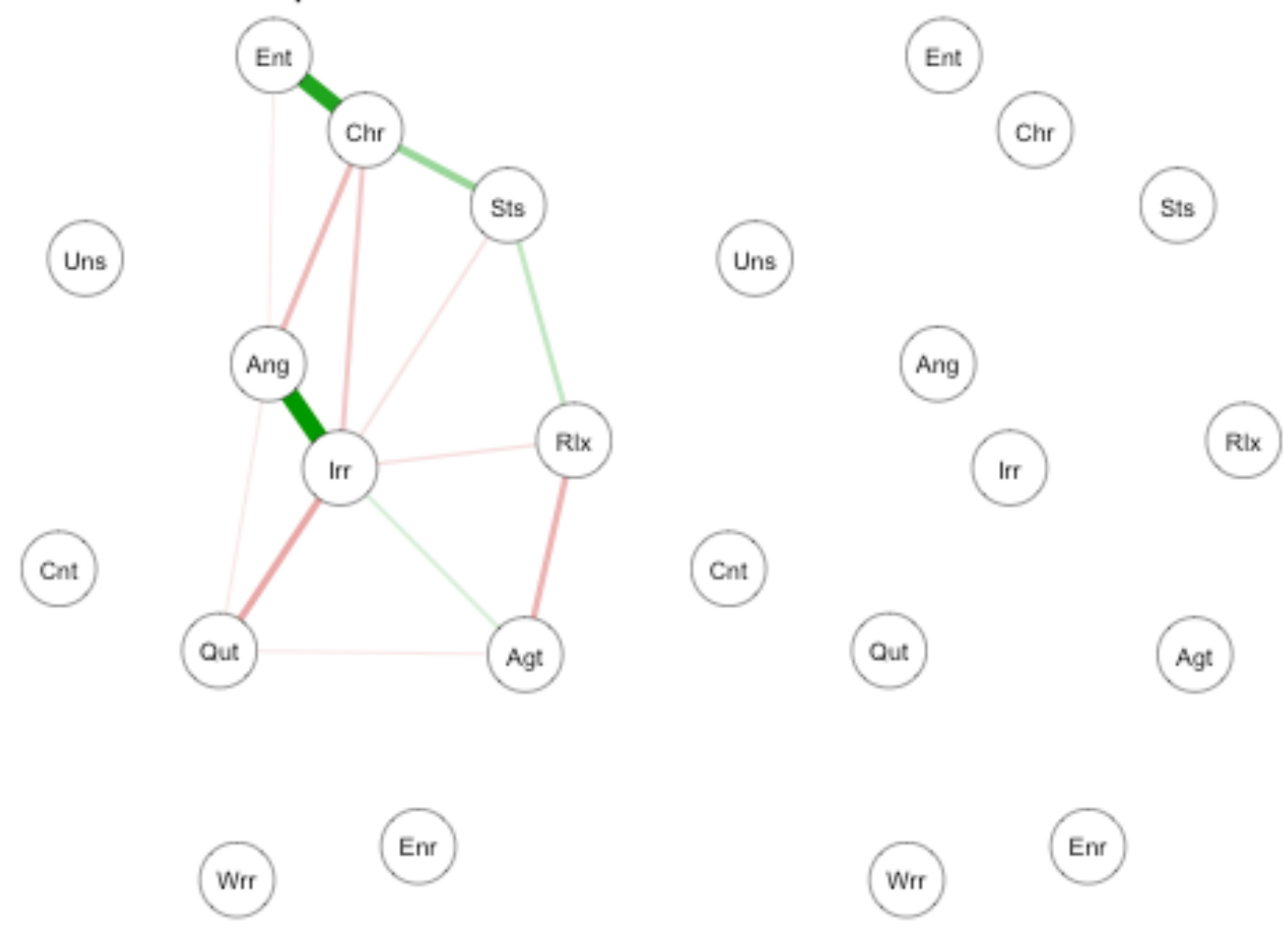

cen.pcc2 = centrality $($ graf.pcc2)

centralityPlot(getWmat(graf.pcc2))

\#\# Note: $z$-scores are shown on $x$-axis rather than raw centrality indices.

\#\# Warning: Removed 4 rows containing missing values (geom_point). 

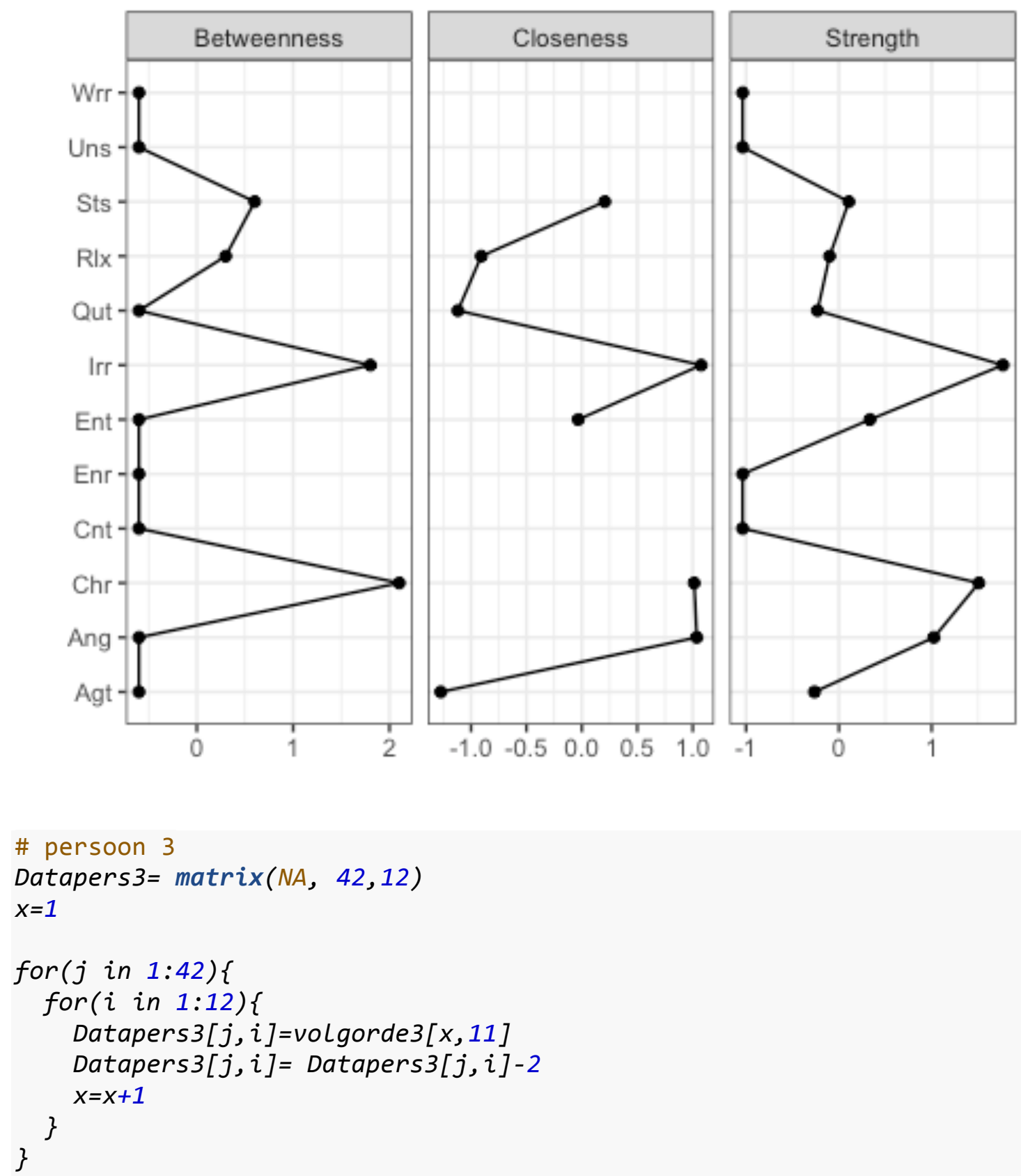
graf.pcc3= plot $(p$ Lot 3, Layout = 'spring', 'PCC')

graf.pcc3.1= plot ( $p$ Lot3, Layout= 'spring', type='temporal')

\#\# Warning in qgraph::qgraph $(x \$ P C C$, Layout $=$ Layout,... , repulsion = \#\# repulsion): The following arguments are not documented and likely not \#\# arguments of ggraph and thus ignored: type

\section{Partial Contemporaneous Correlé}

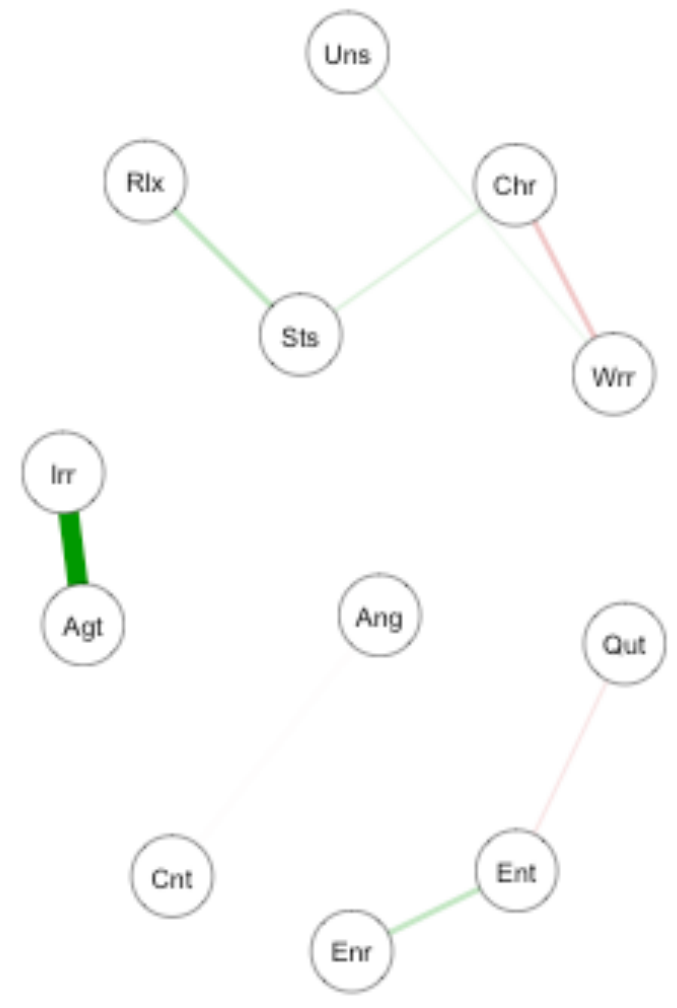

\#\# Warning in ggraph::qgraph $(x \$ P D C$, Layout = Layout, $\ldots$, repulsion = \#\# repulsion, : The following arguments are not documented and likely not \#\# arguments of qgraph and thus ignored: type 


\section{Partial Contemporaneous Correlı́ Partial Directed Correlations}
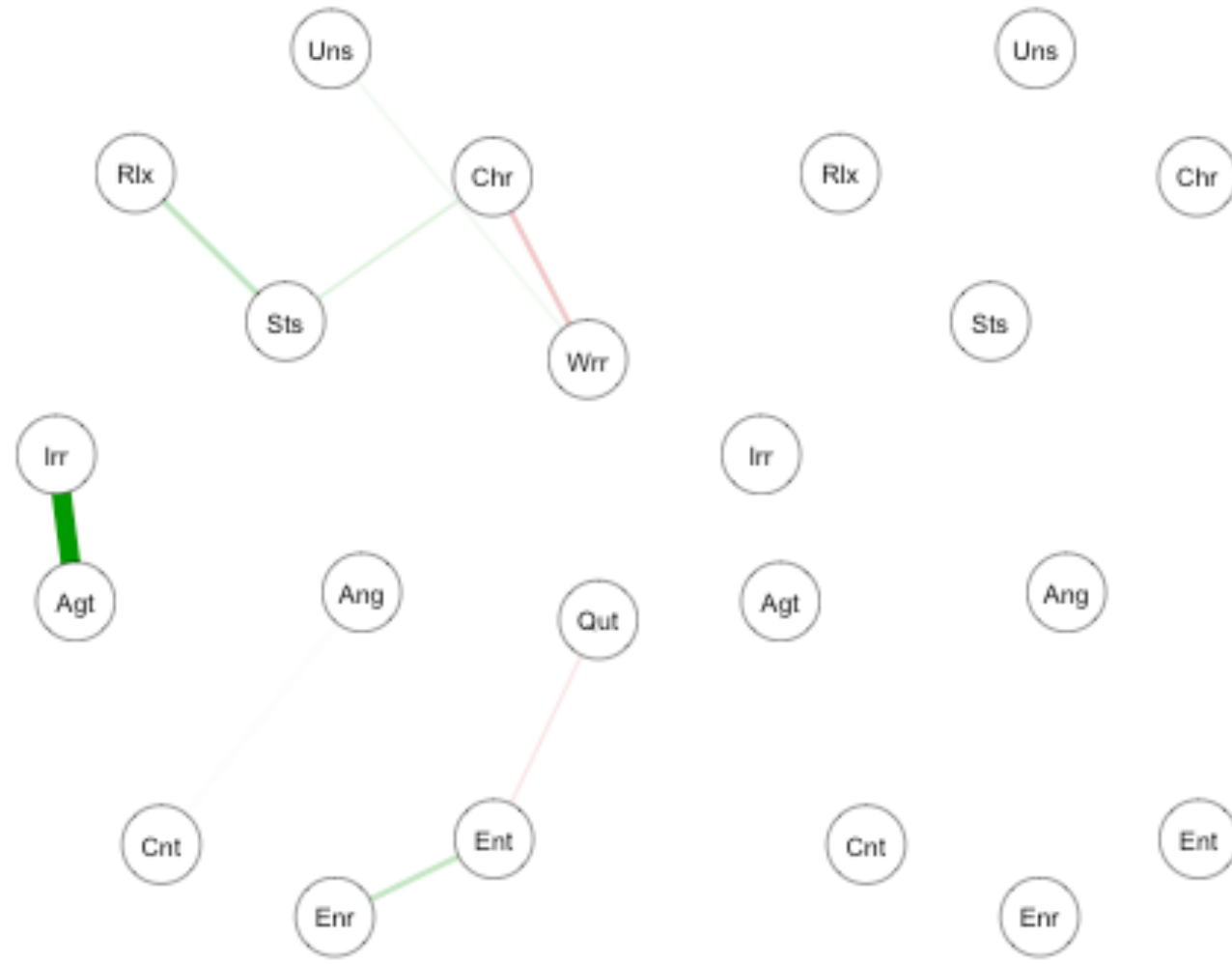

Sts

Irr

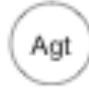

Ang

Qut

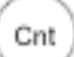

Ent

Enf

cen.pcc3 $=$ centrality $($ graf.pcc3 $)$

centralityPlot(getWmat(graf.pcc3))

\#\# Note: $z$-scores are shown on $x$-axis rather than raw centrality indices.

\#\# Warning: Removed 7 rows containing missing values (geom_point). 

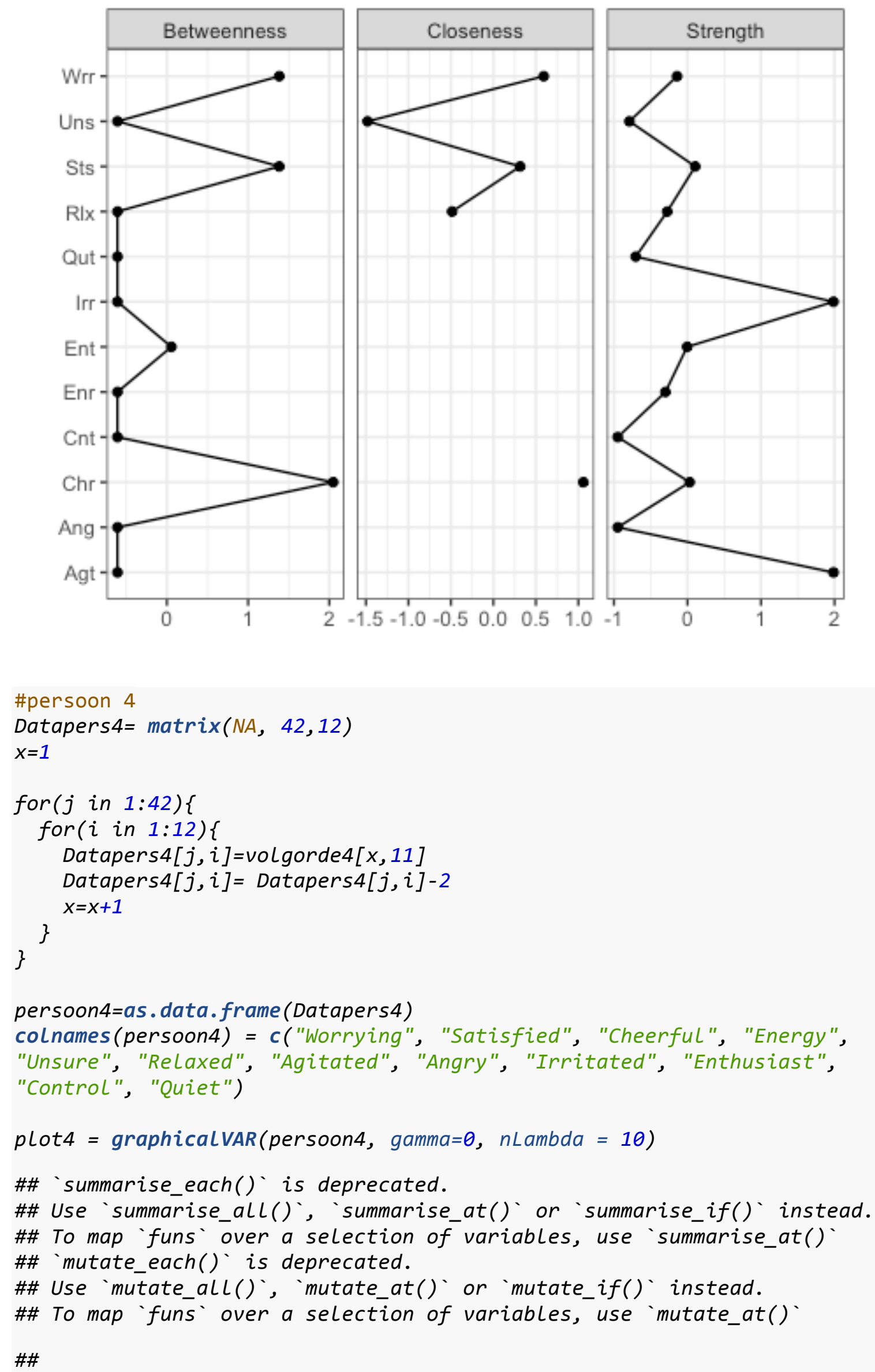
graf.pcc4= plot ( $p$ Lot4, Layout= 'spring', 'PCC')

graf.pcc4.1= plot ( $p$ Lot4, Layout= 'spring', type='temporal')

\#\# Warning in qgraph::agraph(x\$PCC, Layout = Layout, ..., repulsion = \#\# repulsion): The following arguments are not documented and likely not \#\# arguments of ggraph and thus ignored: type

\section{Partial Contemporaneous Correlé}

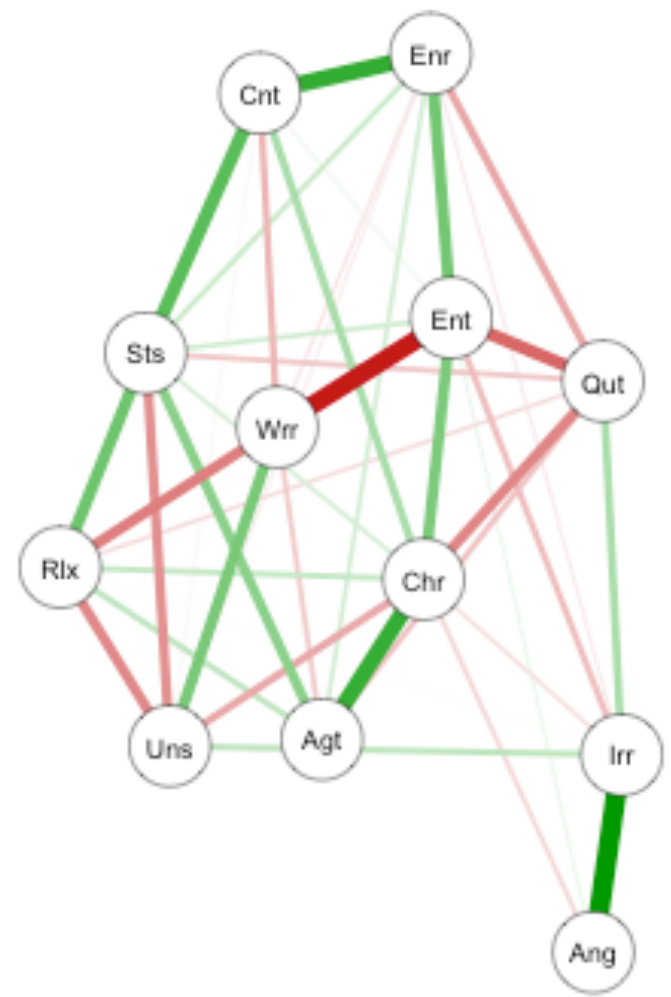

\#\# Warning in ggraph::qgraph $(x \$ P D C$, Layout = Layout,.. , repulsion = \#\# repulsion, : The following arguments are not documented and likely not \#\# arguments of qgraph and thus ignored: type 


\section{Partial Contemporaneous Correlı́ Partial Directed Correlations}
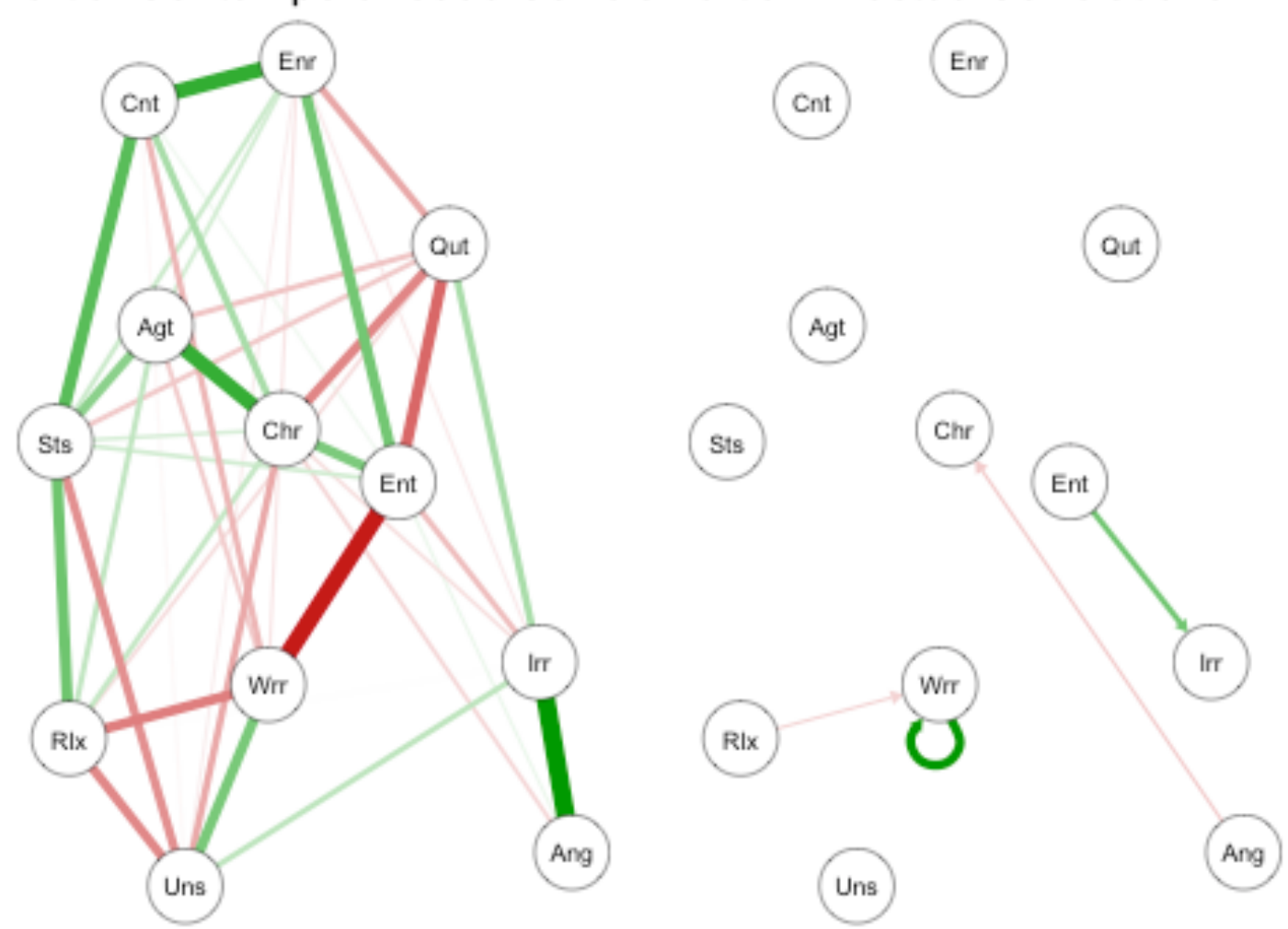

cen.pcc4= centrality $($ graf.pcc4)

centralityPlot (getWmat (graf.pcc4))

\#\# Note: $z$-scores are shown on $x$-axis rather than raw centrality indices. 

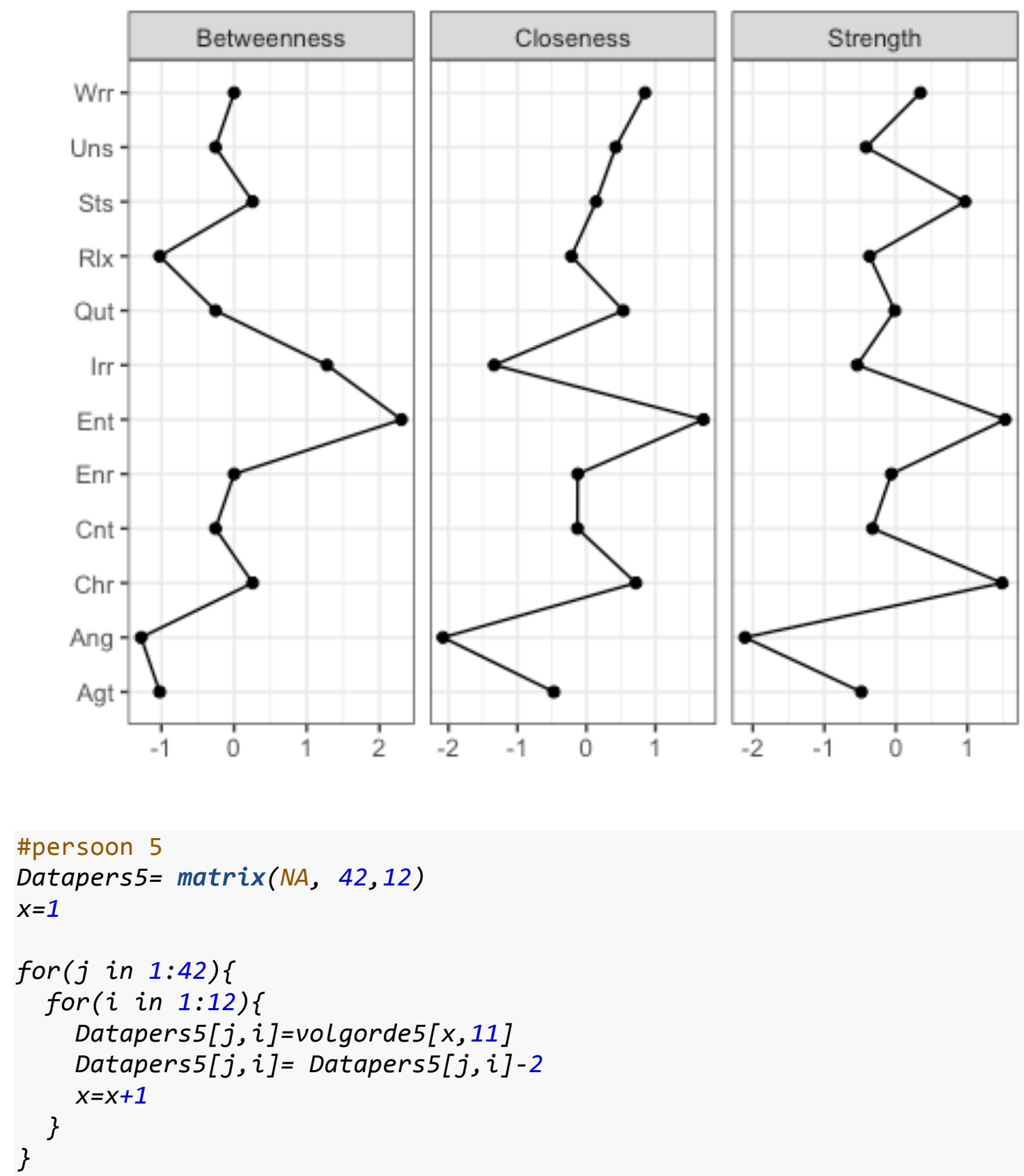

persoon5=as. data . frame (Datapers5)

colnames(persoon5) = c("Worrying", "Satisfied", "Cheerful", "Energy", "Unsure", "Relaxed", "Agitated", "Angry", "Irritated", "Enthusiast", "Control", "Quiet")

plot5 $=$ graphicalVAR (persoon5, gamma=0, $n$ Lambda $=10$ )

\#\# 'summarise_each()' is deprecated.

\#\# Use 'summarise_all()', 'summarise_at()' or 'summarise_if()' instead.

\#\# To map 'funs' over a selection of variables, use 'summarise_at()'

\#\# 'mutate_each()' is deprecated.

\#\# Use 'mutate_all()', 'mutate_at()' or 'mutate_if()' instead.

\#\# To map 'funs' over a selection of variables, use 'mutate_at()'

graf.pcc5 $=p$ lot $(p$ lot5, layout $=$ 'spring', 'PCC')

graf.pcc5.1= plot (plot5, Layout= 'spring', type='temporal') 
\#\# Warning in ggraph::qgraph(x\$PCC, Layout = Layout, ..., repulsion = \#\# repulsion): The following arguments are not documented and likely not \#\# arguments of qgraph and thus ignored: type

\section{Partial Contemporaneous Correlé}

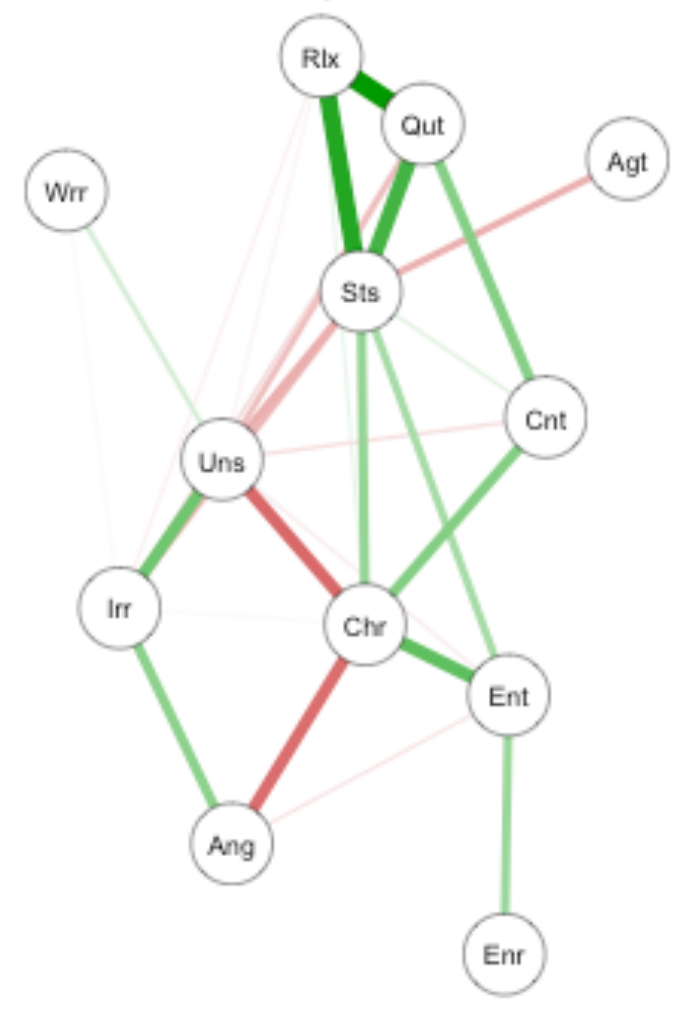

\#\# Warning in qgraph::qgraph( $\$ \$ P D C$, Layout = Layout, ..., repulsion = \#\# repulsion, : The following arguments are not documented and likely not \#\# arguments of ggraph and thus ignored: type 


\section{Partial Contemporaneous Correlı́ Partial Directed Correlations}
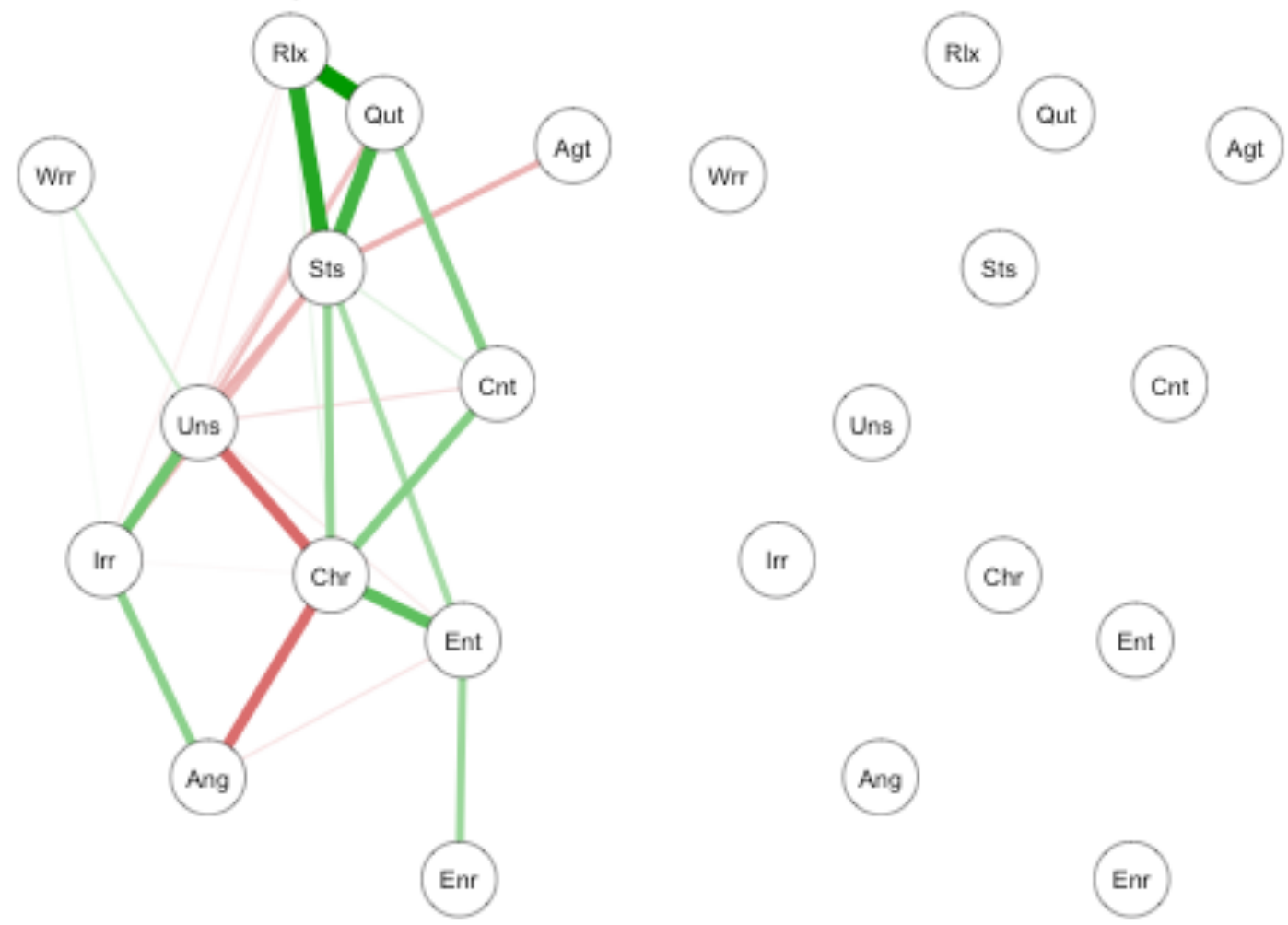

cen.pcc5 = centrality $($ graf.pcc5)

centralityPlot(getWmat(graf.pcc5))

\#\# Note: $z$-scores are shown on $x$-axis rather than raw centrality indices. 

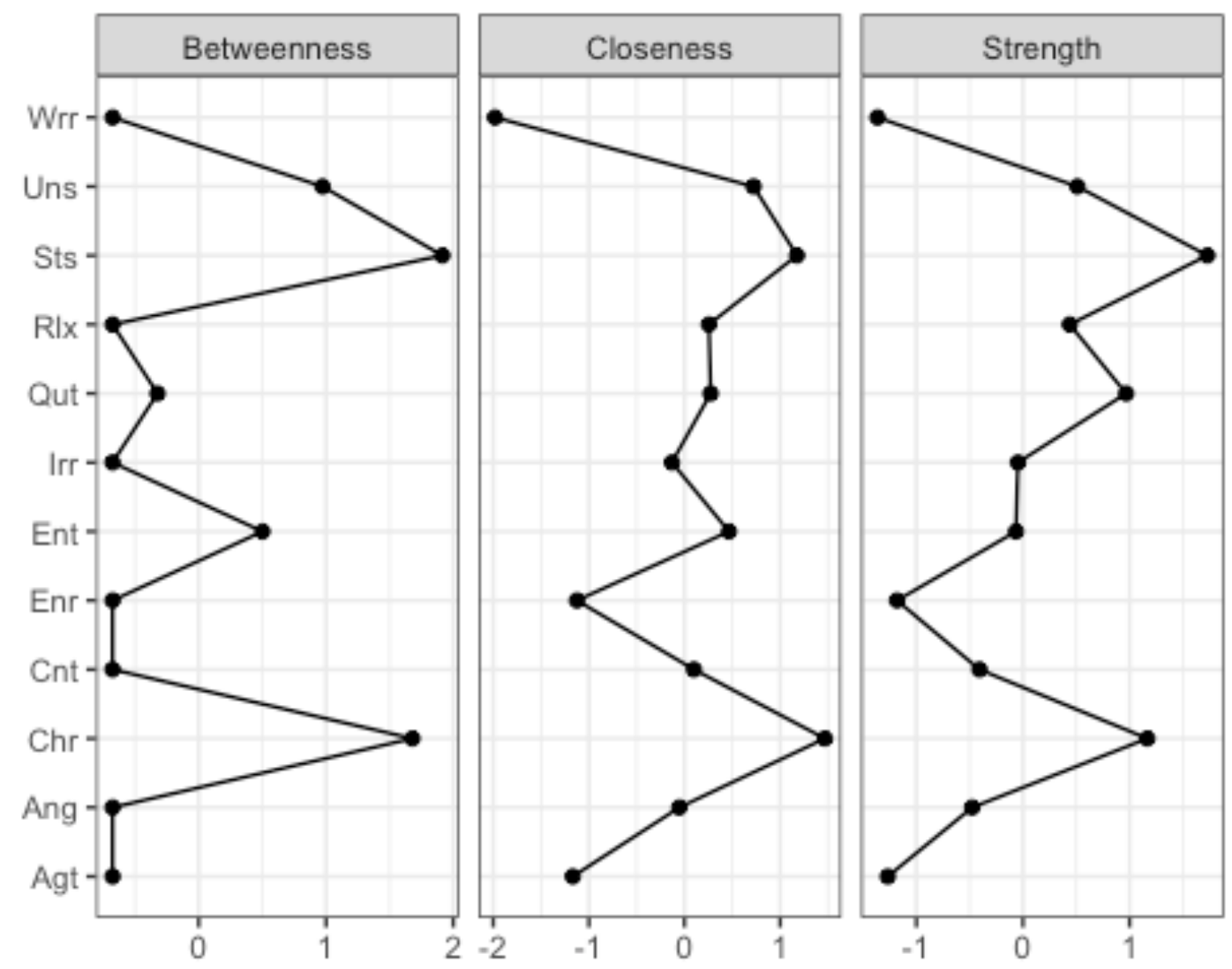

\#\# mLVAr Analyse

\#\# Voor schatten van mLVAR analyse niet de deelnemers, maar alleen de sessie verwijderen

\# verwijderen van overgeslagen sessies

sessie. overges Lagen=vector ()

for (i in 1:nrow(dataset 3$))\{$

if (dataset3\$Response $[i]==$ "\#skipped\#") \{ \}

sessie.overgesLagen [i]=dataset $3 \$$ session. $i d[i]$

\}

weg=unique (sessie.overgeslagen)

data.mLvar $=\operatorname{dataset} 3[!$ dataset3\$session.id \%in\% weg, ]

\# verwijderen van sessies die een NA hebben

sessie.na=vector()

for ( $i$ in 1:nrow(data.mLvar)) \{

if (is.na(data.mLvar\$Responded [i] )) \{

sessie.na[i]=data. $m L$ var\$session. $i d[i]$ 


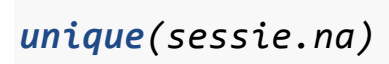




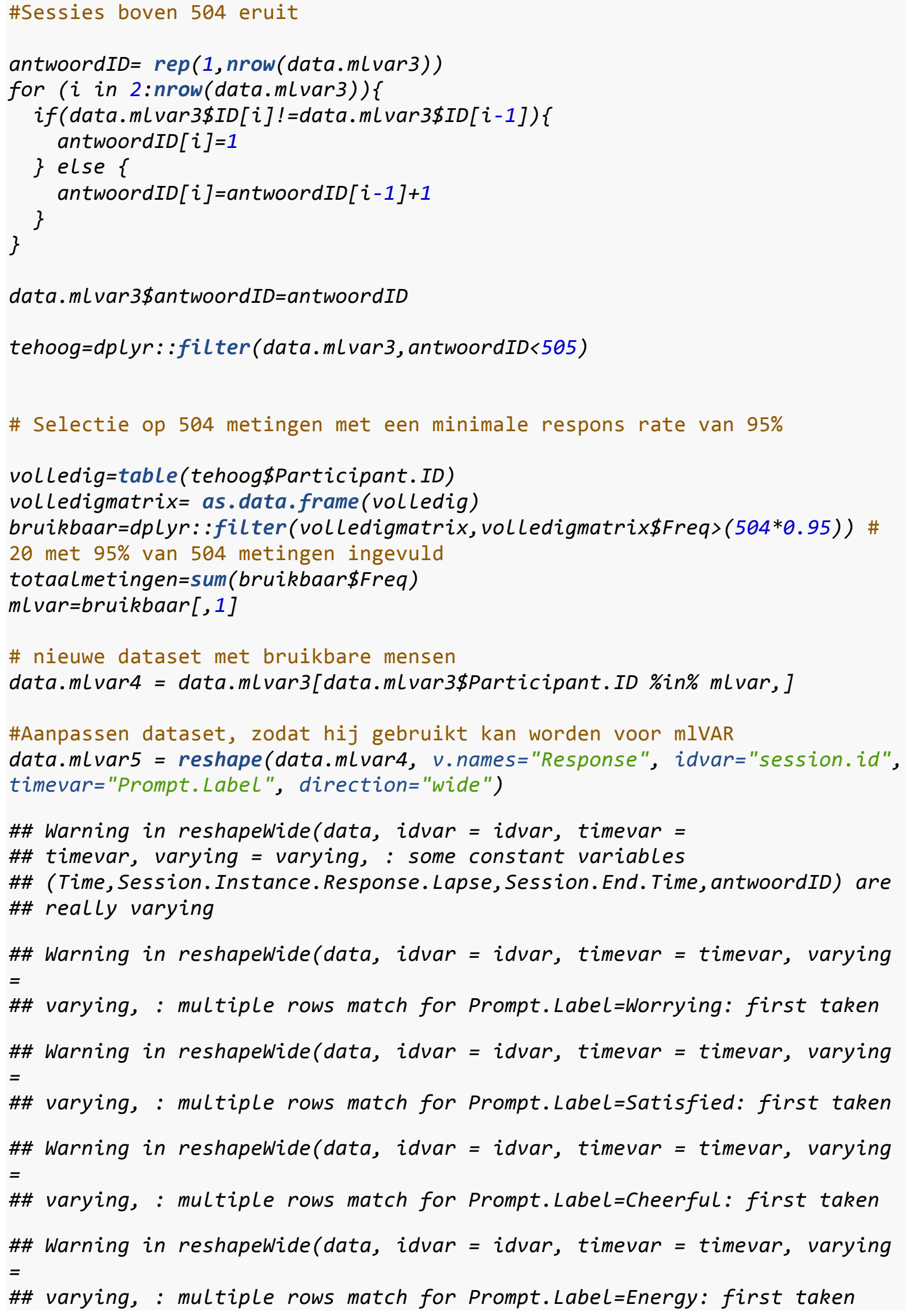


\#\# Warning in reshapewide(data, idvar = idvar, timevar = timevar, varying $=$ \#\# varying, : multiple rows match for Prompt.Label=Unsure: first taken \#\# Warning in reshapeWide(data, idvar = idvar, timevar = timevar, varying $=$ \#\# varying, : multiple rows match for Prompt. Label=Relaxed: first taken \#\# Warning in reshapeWide(data, idvar = idvar, timevar = timevar, varying $=$ \#\# varying, : multiple rows match for Prompt.Label=Agitated: first taken \#\# Warning in reshapeWide(data, idvar = idvar, timevar = timevar, varying $=$ \#\# varying, : multiple rows match for Prompt. Label=Angry: first taken \#\# Warning in reshapeWide(data, idvar = idvar, timevar = timevar, varying $=$ \#\# varying, : multiple rows match for Prompt.Label=Irritated: first taken \#\# Warning in reshapeWide(data, idvar = idvar, timevar = timevar, varying $=$

\#\# varying, : multiple rows match for Prompt.Label=Enthusiast: first taken \#\# Warning in reshapeWide(data, idvar = idvar, timevar = timevar, varying $=$ \#\# varying, : multiple rows match for Prompt. Label=Control: first taken \#\# Warning in reshapeWide(data, idvar = idvar, timevar = timevar, varying $=$ \#\# varying, : multiple rows match for Prompt. Label=Quiet: first taken

\# variabelen

vars=c("Response.Worrying", "Response.Satisfied", "Response.Cheerful", "Response.Energy", "Response.Relaxed", "Response.Agitated",

"Response.Angry", "Response. Irritated", "Response.Control", "Response.Quiet")

\# De factoren 'enthusiast' en 'unsure' kunnen niet meegenomen worden in de analyse, want vertonen te weinig variantie.

for ( $i$ in seq_along(vars)) \{

data.mLvar5[[vars[i]]] <- as.numeric(data.mLvar5[[vars[i]]])-2 \# hier moet dus weer -2 , anders schaal van 3-9 \}

res $=m L$ VAR $($ data $=$ data.$m L$ var 5, vars $=$ vars, idvar $=$ "Participant. ID" $)$

\#\# 'estimator' argument set to 'Lmer'

\#\# 'temporal' argument set to 'orthogonal'

\#\# 'contemporaneous' argument set to 'orthogonal'

\#\# Estimating temporal and between-subjects effects 
plot. cont=plot(res, 'contemporaneous', vsize=18, nonsig='hide', title="Contamporaneous") \# contemporaneous netwerk

cen.mLvar = centrality ( $p$ lot.cont)

centralityPlot(getWmat(plot.cont))

\#\# Note: $z$-scores are shown on $x$-axis rather than raw centrality indices.

plot.temp=plot(res, 'temporal', vsize=16, nonsig='hide', title="Temporal") cen. $m$ Lvar 2 centrality ( $p$ Lot.temp)

centralityPlot (getWmat (plot.temp))

\#\# Note: $z$-scores are shown on $x$-axis rather than raw centrality indices. 